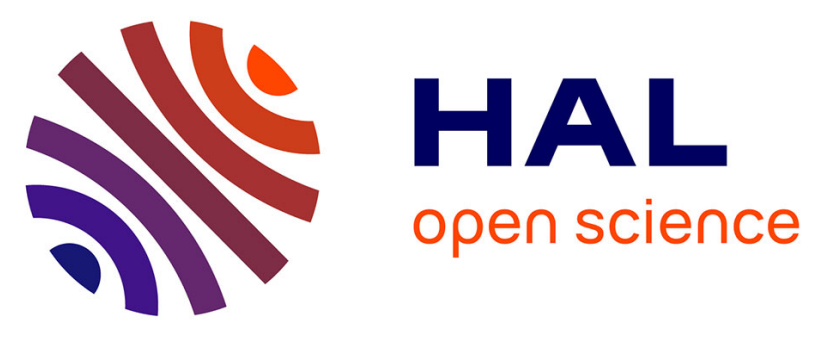

\title{
The one-million-year-old quartz assemblage from Pont-de-Lavaud (Centre, France) in the European context
}

Jackie Despriée, Marie-hélène Moncel, Marta Arzarello, Gilles Courcimault, Pierre Voinchet, Jean-Jacques Bahain, Christophe Falguères

\section{To cite this version:}

Jackie Despriée, Marie-hélène Moncel, Marta Arzarello, Gilles Courcimault, Pierre Voinchet, et al.. The one-million-year-old quartz assemblage from Pont-de-Lavaud (Centre, France) in the European context. Journal of Quaternary Science, 2018, 33 (6), pp.639-661. 10.1002/jqs.3042 . hal-03015938

\section{HAL Id: hal-03015938 \\ https://hal.science/hal-03015938}

Submitted on 20 Nov 2020

HAL is a multi-disciplinary open access archive for the deposit and dissemination of scientific research documents, whether they are published or not. The documents may come from teaching and research institutions in France or abroad, or from public or private research centers.
L'archive ouverte pluridisciplinaire HAL, est destinée au dépôt et à la diffusion de documents scientifiques de niveau recherche, publiés ou non, émanant des établissements d'enseignement et de recherche français ou étrangers, des laboratoires publics ou privés. 


\title{
The one-million-year-old quartz assemblage from Pont-de-Lavaud (Centre, France) in the European context
}

Jackie Despriée (1), Marie-Hélène Moncel (1), Marta Arzarello (2), Gilles Courcimault (3), Pierre Voinchet (1), Jean-Jacques Bahain (1), Christophe Falguères (1)

(1) UMR 7194, National Museum of Natural History, Institut de Paléontologie Humaine, 1 rue René Panhard, 75013 Paris, France

(2) Dipartimento di Studi Umanistici, LT TekneHub Università degli Studi di Ferrara, C.so Ercole I d’Este 32, 44100 Ferrara, Italy

(3) Regional Centre for Archaeological Researches, 18 rue Lindbergh, 41000 Blois, France

\begin{abstract}
The Pont-de-Lavaud site, located in the Centre of France (Creuse Valley), yielded a quartz lithic assemblage composed of a few hundred artefacts with cores, pebble tools, flakes and flake-tools, mixed with several thousand debris and pebbles. The archeological site is covered by a fossil fluvial deposit from the Creuse River (sheet l, with a relative altitude of $+90 / 105 \mathrm{~m}$ ), dated by ESR at the site itself to around $1 \mathrm{Ma}$.

We will focus in this paper on the lithic assemblage with clear anthropogenic features in order to describe the technological strategies applied to quartz pebbles, with the help of experiments. The core technology is based on short "chaînes opératoires" on local quartz aimed at producing pointed end-products on pebbles and flakes. The methods and techniques include both the bipolar technique on an anvil and direct percussion with a hard hammer. The reduction sequences were strongly conditioned by the morphology and the physical characteristics of the raw material. Few flakes are retouched.

The Pont-de-Lavaud lithic assemblage is one example of the diversity of the $1 \mathrm{Ma}$ European industries. The assemblage shows techno-cultural behavioral variability at this period and adaptation to raw material constraints. Comparisons with series where the use of quartz is widespread demonstrate the ability of hominins to use stones of varying quality and to adapt technology to the raw material in zones located beyond the $45^{\circ}$ North parallel.
\end{abstract}

Key-words: Lower Pleistocene, core-and-flake assemblage (Mode 1-type), proto-biface, artefacts, quartz, France, Pont-de-Lavaud

\section{Introduction}

Western Europe is considered to have been occupied before $1 \mathrm{Ma}$. Homo antecessor occupied the South of Europe, continuously or discontinuously, with several dispersals over time. The North, beyond the $45^{\text {th }}$ parallel, would have been episodically occupied when climatic conditions were favorable (Carbonell et al., 2008, 2010; Carrion et al., 2011; Cuenca-Bescos et al., 2011; Mosquera et al., 2013; Rodriguez-Gomes et al., 2014). This could have led to the isolation of small hominin groups and interrupted source dynamics from the South when environmental conditions were unfavorable.

Among these groups, the use of quartz is rare due to the diversity of available raw materials. Early sites, with predominant or secondary use of quartz, are much more frequent in Africa, where they are either located in areas poor in other raw materials or are evidence of a selection by hominins of this stone (Omo 
Valley in Kenya, Olduvai Gorge in Tanzania and Fejej site in Ethiopia for instance, Leakey, 1971; Torre and Mora, 2005; Diez-Martin et al., 2009; Barsky et al., 2011; Delagnes et al., 2011; Gurtov and Eren, 2014; Sánchez-Yustos et al., 2016).

A brief overview of the current data attests that hominins present in the South Caucasus, Georgia, at Dmanisi (1.8 Ma), used diverse local stones, with the occasional use of quartz. It was the same along the Azov Sea at Bogatyri and Rodniki (1.6 to 1.1 Ma), and several sites in Dagestan and Tajikistan (dated to more than 1 Ma) (Martinez-Navarro et al., 1997; Mithen and Reed, 2002; Lordkipanidze et al., 2007; Messager et al., 2011; Shchenlinsky et al., 2008, 2010). Georgian and Russian artefacts (Mgeladze et al., 2011,) are technologically similar to artefacts from East Africa dated to more than 2 Ma (for instance, series such as Kada Gona or Lokalelei, Semaw et al., 1997; Delagnes and Roche, 2005).

In the southern part of Europe, several sites discovered over the past decades attest to the presence of hominins during the Early Pleistocene (Fig. 1) and again to the use of varied local raw materials, including quartz (mainly flint, limestone, sandstone, quartz and quartzite): Pirro-Nord (1.6-1.3 Ma) and MontePoggiolo (900 ka) in Italy, Fuente Nueva 3 (1.4-1.2 Ma), Barranco Leon (1.3-1.2 Ma) and Sima del Elefante and the lower levels of Gran Dolina (1.4-0.8 Ma) at Atapuerca in Spain and Le Vallonnet (900 ka) in France (Lumley de et al., 1988; Martinez-Navarro et al., 1997; Peretto et al., 1998; Falguères et al., 1999, 2002; Falguères, 2003; Arzarello et al., 2006, 2015; Lombera-Hermida de et al., 2016; Michel et al., 2017). These assemblages and related technical behaviors last until 800 ka (Gran Dolina TD3/4 and TD6 and Vallparadis, 900 ka; Carbonell et al., 1999, 2008; Martinez et al., 2014).

\section{Figure 1.}

In the northernmost part of Europe, assemblages also exist as early as $900 \mathrm{ka}$, mostly on siliceous rocks but also occasionally on other stones: Happisburghh 3 (900 ka) and Pakefield (700 ka) in Great-Britain, Soleilhac (900 ka?) and Lunery (1.1 Ma) in the Centre of France near Pont-de-Lavaud, and Kärlich A (900 ka) in Germany, for instance (Bonifay et al., 1976; Bosinski et al., 1980; Würges, 1984;; Bosinski, 2006; Despriée et al., 2006, 2010; Parfitt et al., 2005, 2010). The dating and paleoenvironmental data of these sites confirm that hominins used the main locally available raw materials during favorable climatic phases (see the English sites of Pakefield and Happisburgh; Parfitt et al., 2005, 2010, for instance or MacDonald et al., 2012).

The regional alluvial deposits and the sandy deposits sampled at the site of Pont-de-Lavaud were dated by ESR. The results give an age of around 1 Ma for the fluvial formation overlying the site (Bahain et al., 2007; Voinchet et al., 2010). Located in France beyond the $45^{\circ}$ North parallel, it may be considered as additional data for describing behaviors in an area situated between the South and North, beyond the $45^{\text {th }}$ parallel, and occupied during a temperate period (Marquer et al., 2011; Messager et al., 2011). 
The lithic assemblage is a core-and-flake-type series and the study contributes to better describing technological behaviors in Europe around $1 \mathrm{Ma}$ and the abilities of European hominins to manage quartz, considered as a poor-quality raw material. The Pont-de-Lavaud lithic assemblage stands out from most of the other European sites in that the predominant raw materials are quartz pebbles and vein quartz blocks. The lithic assemblages attest to the diversity of raw material choices, the flexibility of hominin technical behaviors in Europe around $1 \mathrm{Ma}$ and allow for a discussion of the degree of constraints imposed by the exploited raw materials. This paper focuses on the first general study of the artefacts on quartz pebbles from Pont-de-Lavaud with clear anthropogenic activities in order to reconstruct the chaînes opératoires on this type of material in their chronological and stratigraphic context.

\section{Geographic and geological background}

The Pont-de-Lavaud site is located on the right slope of the Creuse Valley, on the commune of EguzonChantôme (Indre, center of France). Jackie Despriée discovered the site in 1982 during geological field surveys and studies on the northern boundary of the Massif Central on the Aigurande Plateau. In this area, the Creuse River, a tributary of the Loire River, flows through metamorphic and magmatic formations (Fig. 2A). The Pont-de-Lavaud site is located on the western slope of one interfluve between the Creuse Valley and a small tributary (Fig.2B). The river flows along deep grabens because the Aigurande Plateau is a tectonic area in which major faults and anticlines formed many tilted blocks. The Pont-de-Lavaud site is located on the top of a block recently tilted to the west (Despriée and Gageonnet, 2003: Despriée et al., 2006).

During geological fieldwork, test pits revealed remnants of the alluvial formation Sheet 1 on the Fressignes interfluve (Fig. 2B). Excavations were carried out on the top interfluve in the hamlet of Fressignes, revealing a thickness of about $1.50 \mathrm{~m}$.

On the western slope, at Pont-de-Lavaud, along a one-hundred-meter cross-section, remnants of Sheet 1 were also observed, overlying a diamicton deposited on the micaschist bedrock. Some fresh broken quartz pebbles, abundant fresh quartz debris and one flake presenting signs of knapping and possible retouch, were recovered in situ. These artefacts were mixed in a thin layer of quartz pebbles overlying the top of the diamicton (Despriée and Gageonnet, 2003).

\section{Figure 2.}

At Pont-de-Lavaud, excavations were conducted over a period of twelve years (from 1984 to 1995). The archaeological level stratified on a thin layer of quartz pebbles deposited on the top of diamicton and under a fluvial sandy deposit was studied over a surface of one hundred and thirty square meters. This level yielded abundant quartz lithic elements composed of about 8,000 broken cobbles, debris, and cores and 
flakes (whole pebbles not included). These artefacts were lying on and around two accumulations of large vein quartz blocks and cobbles, interpreted as anthropogenic pavements (Despriée et al., 2006, 2010, 2011).

\section{Stratigraphy of the Pont-de-Lavaud Site}

Multidisciplinary research at the site and the geological background enable us to propose five successive chronological phases of sedimentary formation at Pont-de-Lavaud in response to glacial-interglacial phases (stages A to E, Fig.3):

A - Micaschists with veins of quartz and amphibolite (bedrock, unit 0), incised by the Creuse River. Micaschists were then weathered in places into clayey alterites (Unit 1, Fig. 3A).

B - A coarse slope deposit, extending over a surface of about $200 \mathrm{~m}^{2}$, overlaid part of this bedrock (diamicton, unit 2, Fig. 3B). It contained various types of very altered rocks (amphibolite, gneiss, micaschists) and weathered quartz mixed in a very clayey, gravelly and coarse sandy matrix. These materials were transported by solifluction from the plateau and reworked former fluvial sediments (Despriee and Gageonnet, 2003). This shape and the frontal edge of this deposit were similar to terminal lobes of debris flow (Cojan and Renard, 2006).

\section{Figure 3.}

C - The diamicton was then disturbed by periglacial features, like clay injections (diapirs) and stone clusters during freeze/thaw cycles during a Pleniglacial phase (Fig. 3C). The micaschist bedrock was also severely cryoturbated, as attested by polygons and ice wedges. The regular circular and polygonal shapes indicate that cryoturbation occurred at the top of a horizontal faulted block (Despriée and Gageonnet, 2003).

D - At the beginning of the following interglacial, a thin alluvial layer of well-calibrated pebbles $(4-6 \mathrm{~cm})$ was deposited by the Creuse River and covered the bottom of the diamicton (Despriee and Gageonnet, 2003). Hominins gathered quartz pebbles and cobbles in this layer for breaking and may possibly have carried blocks for pavements. The part of the archaeological level identified during excavation extends both over the micaschist bedrock (south area), and on this pebble layer (northern area) (Fig. 3D). According to palaeobotanical studies, hominins settled in a forested context during a hot and wet temperate interglacial period of the Early Pleistocene (Marquer et al., 2011; Messager et al., 2011

E - The archaeological level was covered by fluvial sands (unit 3, Fig. 3E) of the Pont-de-Lavaud/le CerisierFormation (sheet I of the Creuse system, Fig. 4). These alluvia protected the archaeological level from erosion during most of the Pleistocene (Despriée and Gageonnet, 2003; Despriée et al., 2004, 2006).

F - After Pleistocene tectonic events (fault displacement and thrust, and the recent tilting of the Pont-deLavaud block (Holocene), the sandy sheet was then eroded and the site is now largely exposed (Fig. 3F) 
(Despriee and Gageonnet, 2003). Fortunately, no heavy farm machinery was ever used on the site. The meadow was cultivated in the past with ox and a wooden swing-plough, and furrows were observed at a depth of around $10 \mathrm{~cm}$.

\section{Geochronological data}

In the Eguzon area, the Creuse River fluvial system is made up of 11 fossil fluvial formations stepped on the two slopes and named from the lowest to the highest A to K. All the sheets and remnants are dated by the ESR method applied on bleached fluvial quartz. The ages range between 130 ka (sheet $A, 0 /+5 \mathrm{~m}$ and 1.7 Ma (sheet $K_{\bar{T}}+115-+130 \mathrm{~m}$ rel. (Voinchet et al., 2007, 2010) (Fig. 4).

In the Eguzon area, many remnants or outliers of the fossil fluvial sheet I are located over about $15 \mathrm{~km}$ along the slopes of the Creuse Valley. Thirteen ESR dates on quartz sands sampled in the best-preserved remnants provided coherent results with good reproducibility. Hence, the ESR ages of Sheet I, covering the Pont-de Lavaud archaeological layer, are scattered between 1.2 and 1.1 Ma (Falguères et al., 2002; Falguères, 2003; Despriée and Gageonnet, 2003; Despriée et al, 2004, 2006, 2010; Voinchet et al., 2007). The best ESR weighted mean age estimate of the sandy fluvial deposits from the Pont-de-Lavaud/le Cerisier formation is presently 1,055 $\pm 55 \mathrm{ka}$ (Lombera -Hermida et al., 2016).

\section{Figure 4.}

Eight ESR samples were taken directly from the Pont-de-Lavaud site. Three of them were sampled in a thick sandy lens in the diamicton underlying the archaeological level. The ages obtained are $964 \pm 100 \mathrm{ka}, 1031 \pm$ $150 \mathrm{ka}$ and $1054 \pm 100$ ka respectively (Fig. 3, F, samples 1 ). Three other samples were taken in the fluvial deposits overlying the archaeological level. The results are $905 \pm 100 \mathrm{ka}, 1001 \pm 150 \mathrm{ka}$ and $977 \pm 100 \mathrm{ka}$ respectively (Fig. 4, F, samples 2). One sandy sample from the archaeological layer, at the same level as the palaeobotanical samples, was dated to $960 \pm 60$ ka (Fig. 3, F, sample 3) (Voinchet, 2002; Despriée et al., 2004; Voinchet et al., 2010 . Lastly, an age of $220 \pm 40$ ka obtained on a sample taken in the sandy deposit close to the diamicton termination is absurd (Fig. 3, F, sample 4, Garon, 2014)

The ages obtained from sands sampled at the site of Pont-de-Lavaud are slightly younger than the ages obtained for the sands sampled in Sheet I. This was interpreted as a consequence of the important weathering of the sediments (Despriée and Gageonnet, 2003). For the samples taken from the archaeological level and in the underlying alterite, geomagnetic polarity is normal and could correspond to the normal Jaramillo subchron (1,06 to 0,9 Ma, Cande and Kent, 1995), during the Matuyama Chron reversal. 
These ESR and paleobotanical data enable us to propose a record of the early glacial, pleniglacial and interglacial deposits at Pont-de-Lavaud. The short gap between the ESR ages should indicate that these levels were deposited during the same glacial/interglacial climatic cycle.

These ESR dates and vegetation suggest that the Pont-de-Lavaud site is related to an Early Pleistocene temperate period around MIS 31 (Liesiecki and Raymo, 2005).

\section{Quartz assemblages}

At Pont-de-Lavaud, excavations and geological observations were conducted over a surface of $130 \mathrm{~m}^{2}$, in order to recover quartz elements resulting from anthropogenic actions, to locate the stratigraphic position of the artefacts, record the precise location of each piece and characterize their deposition mode and distribution.

Excavations concerned the southern surface of the micaschist bedrock, the layer of pebbles $\left(130 \mathrm{~m}^{2}\right)$ (Fig. $5)$, then the diamicton itself $\left(50 \mathrm{~m}^{2}\right)$ and below that, the surface of the bedrock $\left(30 \mathrm{~m}^{2}\right) . \ln$ this way, each quartz item was collected with zenithal and plane square meter view photos or planes (scale=1/10), then described in the laboratory.

In order to locate the original deposits of quartz present in the different sedimentary units at Pont-deLavaud, fieldwork observations were conducted on the Aigurande Plateau and Marche area, (Fig 2A) with petrological analysis. Extensive experimental work was added to prospection in the neighboring cultivated fields to check whether broken pieces and pieces with scars are artefacts or geofacts, or, because of the limited thickness of the overlaying sand, recent clasts produced by heavy farm machinery.

\section{Original deposits of quartz materials}

Around the Pont-de-Lavaud site, the structural units making up the Aigurande Plateau are thrust sheets of metamorphic rocks and intrusive magmatic batholiths. These different units are visible along tectonic accidents, or on the eroded surfaces of the plateaus (Fig.2 A) (Rolin, 1981; Cohen-Jullien et al., 1989, 1998). In the metamorphic units, there are many series of amygdaloid gneiss with numerous almonds (amygdales) of quartz, elongated and flattened by foliation. These ovoid and flat almonds of grey quartz were generally heavily recrystallized during new phases of metamorphism and new thrusting or subsequent magmatic extrusions and have a quartzitic aspect (Chenevoy, 1968; Bouloton, 1974; Rolin, 1981; Rolin and Quenardel, 1980; Cohen-Jullien et al., 1989, 1998). In the magmatic units, plutonic batholiths of intrusive leucogranite contain a profusion of vein quartz (Rolin and Quenardel, 1982). This white quartz was also metamorphized and recrystallized and has a metaquartzitic aspect. Despite their hardness, almond or vein quartz included in metamorphic and magmatic units were fractured during subsequent tectonic events.

During Tertiary Periods, after the erosion of the metamorphic or magmatic formations, the quartz elements were carried and spread by high-energy river-flow over the surface of the Aigurande Plateau. The cobbles and blocks observed on the surface of the plateau show whole well-rounded surfaces, and no fractured 
surfaces. During the Quaternary Period, the non-porous quartz was not sensitive to frost. In the sedimentary deposits of the Middle Creuse River valley, we found no marks of frost-shattering in cryoturbation features, slope deposits, no cracks, no scars, or joining fragments on the surface.

At Pont-de-Lavaud, almonds of metamorphic quartz and weathered cobbles and boulders of vein quartz are present. In the archaeological level, three groups of quartz objects were initially distinguished (Fig. 5):

- A thin layer of small well-calibrated quartz pebbles and cobbles (4-6 cm long) with whole weathered morphology and smooth surfaces (fluvial pebbles and whole quartz almonds (Despriee and Gageonnet, 2003). The layer was deposited at the beginning of phase $D$ and was spread on the bedrock (northern area), on alterites (eastern area), on the bottom of the diamicton (central area), and on sands (southern area) (Fig.3d);

- Underlying this pebble layer were many big cobbles and weathered vein quartz boulders aggregated on two coherent surfaces named Pont-de-Lavaud 1 and Pont-de-Lavaud 2 (Suppl 1 and 2A and B, Fig. 5).

These two regular ovoid surfaces are about $9 \mathrm{~m}$ long and $3.5 \mathrm{~m}$ wide. The shape of these two similar accumulations is very different from the circular or polygonal shapes of the periglacial features observed in the diamicton. The large cobbles (> $10 \mathrm{~cm}$ wide) and boulders are aligned on the perimeter. We observed an accumulation of artefacts and debris quartz on these perimeters (type wall-effect). Holes filled with beige sand from the overlying fluvial formation were associated with wedging cobbles (type post-holes). We advanced the hypothesis of a primitive shelter (Despriee et al, 2011).

\section{Suppl. 1. \\ Supp. 2A}

- As scars due to human breaking were not visible straightaway, all the quartz elements were recorded on the excavation surface. In the laboratory, each piece was sorted and the following characteristics were described: raw material, type of clastic element, shape and size, mechanical or chemical weathering, or anthropogenic marks. More than 8,000 freshly fractured quartz elements were found, mixed in with the pebble layer and between the cobbles and boulders of Pont-de-Lavaud 1 and 2. All in all, 4,800 presumed anthropogenic broken cobbles, pebble fragments, pebble debris, and flakes from cobbles were identified. Rare cores were also recorded. 3,500 pieces of fresh local vein quartz were also densely distributed on and around Pavement 1 , and more sparsely spread in and around Pavement 2.

However, since the different types of metamorphic quartz are very hard, hominins would have had to break them on site, as suggested by the recorded anvils, passive hammer and hammer stones (Fig. 5). So, typical marks should be observable on the products, as described on similar sites or after experimentations (Crabtree 1972; Shott, 1989; Leakey and Roe, 1994; Curtoni, 1996; Mourre, 1996; Mourre and Jarry, 2004). 
They have clear anthropogenic scars or strong percussion impact marks, described as anvils, passive hammers, and hammer-stones, broken pebbles with one or several angular fresh surfaces, fresh edges with scars looking like impacts, with cracks and some retouch, fragments and debris, pebbles with organized removals (considered as cores) and flakes.

Studies of the fresh vein quartz elements are in progress. In this paper, we present the experiments and studies of the broken pebbles.

\section{Figure 5.}

\section{Quartz Industry}

The pebble layer thus provided a source of pebbles and cobbles that could be used by hominins. As observed (see above) on the surface of this layer, apart from the blocks grouped together in oval surfaces, the mean length of the cobbles is between 40 and $60 \mathrm{~mm}$ and the mean width and thickness are about 40 mm Fig. 6).

\section{Figure 6.}

The 4,800 presumed broken cobbles were classified into four categories:

1) The first category comprises almonds, well-rolled or weathered pebbles, cobbles, and quartz blocks, with smooth surfaces and edges. These morphologies and weathering are typical features of high-powered and long-distance fluvial Tertiary transport, as described above. They have no fresh scars, impacts or acute angles. Some of them, with an orthogonal flat surface, broken by tectonic events before fluvial transport, also bear such weathered fractured surfaces that the crystal surfaces are no longer visible (types 1 and 2, Fig. 7).

\section{Figure 7.}

2) The second is composed of the same cobbles and pebbles with impact points and scars that seem to be due to crushing, peeling or flaking (hammers?). All the scars are very fresh, with no signs of weathering, but with local alterite clay and very thin iron deposits on the damaged surfaces (types 3 and 4, Fig. 7).

3) The third class comprises broken cobbles and pebbles with plane, salient or re-entrant angles. Breaking surfaces are fresh with apparent crystallization and angular edges. These pieces have partially preserved the morphology of the original quartz materials (types 5 and 6, Fig. 7).

4) Fragments of cobbles and pebbles, which generally have three surfaces with dihedral angles: a wellrounded surface and two freshly broken surfaces intersecting at acute or right angles. The surfaces are generally plane, but not smooth, with visible fine aggregation of small crystals. Older and more recent surfaces are intersected by two trihedral ends. These ends display visible crushing, associated with cracks 
and small negative debris. Other impact marks are also visible on other parts of the perimeter, generally on the opposite edge, linked to the main scar by one or two ridges (types 7a, b, c and d, Fig. 7). Generally, similar scars are observed on these pieces: one or more circular impacts $(\varnothing=2 \mathrm{~mm})$ on the edge of the natural smooth surface and the more recently broken surface. Numerous shocks or impacts are often visible on the opposite surfaces. These impacts are associated with other scars such as cracks, small breaks, ridges or rises.

In order to verify if these broken pieces and pieces with fresh scars are artefacts or geofacts, or recent clasts produced by heavy farm machinery, given the limited thickness of the overlaying sand, extensive fieldwork observations in addition to experimental works, were conducted.

Natural processes and marks, clearly resulting from transportation by rivers, solifluction or gelifluction and frost clasticity, are well known and helped us to distinguish marks due to natural or anthropogenic processes. Natural pieces may be very similar to artefacts-and researchers have clearly described common geofact features, such as thin removals related to the natural shape of the stones but also the lack of clear percussion points or striking platforms (Commont, 1909, Obermaier, 1912, Pei, 1936, Raynal et al., 1995, 1996; Raynal and Magoga, 2000; Niang, 2014; Wisnievsky et al., 2014).

At Pont-de-Lavaud, the remetamorphised quartz is very hard and cannot be broken by transportation (energy river-flow). The cobbles and blocks show completely well-rounded surfaces. When resilicified, they are not porous and are not sensitive to frost. We found no evidence of frost-shattering, such as cracks, scars, or joining fragments in the cryoturbated diamicton, or on its surface, or in the layer of small cobbles and almonds where hominins gathered the raw material.

These truncated cobbles, fragments or cobble debris with unweathered surfaces and angular edges, as well as the blocks of quartz with impacts on their surface edges, suggest that the very hard metamorphic quartz pebbles may been have broken by hominins. So, experiments breaking of quartz were requisite and essential to characterize evidences of anthropogenic processes.

\section{Breaking experiments}

First, breaking experiments were tested, using direct percussion with quartz hammer. We could not obtained flakes or debris because of the hardness of quartz almonds. So, we experiments with anvils with quartz hammers as those that were discovered in situ during excavation (Fig. 5).

1) Tests on anvils

Several blocks of vein quartz were used as anvils. Three of them display similar dimensions to those found at the excavation. One hundred quartz pebbles were broken on these anvils using a quartz hammer stone, also gathered on site. 
During experimentation, we observed a white powder deposit on the surface of the anvil. This powder results from the crushing of the quartz surfaces when impacted by the hammer stone and from points of contact with the surface of the anvil on the other side. These crushing scars are clearly visible on the broken pebbles and fragments (Fig. 8).

Hammer impacts with the upper surface of the anvil are quite rare but they produce typical impacts. These only occur when a stone or fragment slips. After use, some strikers only bear characteristic crushing. Others have a broken tip after prolonged use. Some split quickly due to mica planes in the almond quartz.

\section{Figure 8.}

For the experimentations, we used the same type of quartz and reproduced similar marks to those described at similar sites (Crabtree, 1972; Shott, 1989; Leakey and Roe, 1994; Curtoni, 1996; Mourre and Jarry, 2004; Barsky et al., 2015; Hayden, 2015; Li, 2016, Torre and Hirata, 2015; Li Feng , 2016 RodríguezÁlvarez, 2016; Li Hao et al., 2017). Geological data indicate that the pebble layer was a possible source of raw material for hominins. The mean length of the pebble layer cobbles is comprised between 40 and 60 $\mathrm{mm}$ and the mean width and thickness are about $40 \mathrm{~mm}$ (Fig. 6). They are well rounded (Fig 8). The different types of available metamorphic quartz are very hard. Since pebbles with clear impact marks were recorded on the site, we considered that hominins could have broken pebbles and cobbles directly on the site (Fig. 5). As these marks were not immediately visible during the excavation, all the quartz pieces from the layer were recorded in the laboratory, and each piece was described on the basis of the following criteria: raw material type, type of clastic element, shape and size, mechanical or chemical weathering and possible marks.

Experimentation was conducted with local raw materials in order to reproduce the same marks as the recurrent marks observed in the second, third and the fourth classes and compare them. We used similar cobbles and pebbles to those with strong impact marks (described as anvils and hammer stones) found during the excavation. The experiments lasted for 20 years and increased in intensity over the past five years (Lombera-Hermida et al., 2016). They involved between two and 10 specialists with diverse expertise.

2) The breaking tests

More than 1,000 cobbles chosen for the experiment were gathered according to the dimensions and quartz types recorded in statistical studies. Some of them were impossible to break (3\%) because they were remetamorphized and lateritized and thus too hard to fracture. The others were broken by the first, second or third blow. When they break at the first blow, they break anywhere, depending on the contact zone with the surface of the anvil. Two fragments of unequal size were generally obtained (Fig. 9, types 5 and 7a). However, cobbles can also be broken into three parts (Fig. 9, types 5, 6 and 7c -7d). Breakage occurs when the shock wave reverberates through each point of contact with the surface of the anvil. It is not conchoidal 
breaking. Due to the very hard recrystallized quartz grains, the shock wave follows the facets of the small crystals. The freshly ruptured surfaces are generally orthogonal to the smooth surface struck by the hammer stone, they intersect at right angles and do not bear cutting edges. Other cobbles were broken after several blows, resulting in the production of smaller and sharper debris owing to the presence of multiple cracks opening during the last blow (Fig. 9, types 5, 7 and 8).

Some marks are systematically observed: (1) One or more circular impacts $(2 \mathrm{~mm})$ with a dent in the quartz rock $(1 \mathrm{~mm})$, on the upper surface, (2) On the edge of the broken surfaces, these impacts are associated with cracks, breaks and elevations connecting hammer impacts and crushing on the opposite side, (3) For one blow to the upper surface, one or more scars are visible on the opposite surface, depending on contact with the anvil surface, and (4) All these scars are similar to the marks observed on the presumed anthropogenic artefacts recorded in the pebble layer.

\section{Figure 9.}

Experimentation obtained similar morphologies and typical scars, such as impacts, crushing, and fresh broken pebble surfaces (Supp. 3). Fragments and debris are consistent with the fragments and debris recorded during the excavation (see Fig. 10). Impact marks on the hammer stones and anvils are also similar and provide evidence of fragmentation of human origin. The numerous impacts on the anvils discovered on the site suggest more prolonged use than during experimentation, accounting for the discovery of the large number of fragments or debris.

As demonstrated by the experiments, conchoidal fractures do not occur on this type of quartz and cannot be taken as a criterion of hominin intervention. When quartz is broken, there is neither a bulb on the artefacts nor bulb negatives on the block. The wave moves linearly and the scar negative has a slightly curved profile and section. The petrographic history and characteristics of the Pont-de-Lavaud quartz demonstrate that natural processes could not have fractured these rocks. No breakage at Pont-de-Lavaud corresponds to the action of long depositional processes on natural materials, described for instance by De la Torre and Mora (2005) in some African sites. Our series incorporates by-products and end-products resulting from percussion flaking on quartz. Our experiments therefore show that part of the quartz artefacts are due to anthropogenic action and are not geofacts.

\section{Supp. 3.}

\section{The anthropogenic record. Fragments of pebbles, debris, cores, flakes and retouched pieces.}

We present here the results on 1,321 pieces made on rolled or used pebbles and cobbles. They were selected on the basis of their marks with regard to the experiments, and systematically analyzed in detail 
(Table 1). We will not presently discuss the assemblage composed of vein quartz, which is still being studied, on account of the difficulties inherent to the interpretation of this kind of raw material.

The series is composed of: (1) Fragments and pebble debris with percussion marks and with marks considered to be by-products of percussion flaking, (2) Pieces with several organized removals considered as cores (with striking platforms and scars) or pebble tools, (3) Unretouched flakes, and (4) Flakes or debris with retouch (Table 1 ).

The spatial distribution of the different categories does not show any particular organization. This could be explained by the accumulation of several periods of occupation and/or by the dense activity at the site. Few pieces have been refitted due to the large quantity of fragments and debris. Most of the refits come from the same square. The only types of pieces that seem to be associated with the two concentrations of artefacts are the retouched blanks and the partial bifacial piece that were found in these zones (Fig. 5). Eight squares are also characterized by the absence of lithic material. This is not due to the presence of blocks and these zones are considered to be true negative areas.

\section{Figure 10.}

\section{Modes of percussion and processes performed on the site}

As a result of the experiments, we can assume that two techniques of percussion are documented in the assemblage: direct hard hammer percussion or bipolar percussion on an anvil, depending on pebble morphology (Table 1, Fig. 11). Cores with organized removals and flakes with a striking platform indicate that direct hard hammer percussion was performed at the site.

\section{Figure 11.}

The bipolar percussion technique is observed on half pebbles through the identification of one or two opposite butts and the presence of trimming or marginal retouch on the extremity of the half pebbles. It was used during knapping depending on the quartz structure and the pebble shape. The pebble was struck on the anvil with a hammer stone (see Vergès and Ollé, 2011). There is no bulb due to the physical characteristics of the raw material, and it is often difficult to distinguish the positive and negative parts of the pebble (two half pebbles at least). The fracture is referred to as a "split fracture". This type of breakage produces pieces with specific marks; several shattered sides and a polygonal section. These characteristics are frequently cited in the literature (e.g. Cancellieri et al., 2001; Mourre, 1996; Mourre and arry, 2004; Faivre et al., 2010; Lombera-Hermida et al., 2011; Garcia et al., 2013; Zaidner, 2013; Gurtov and Eren, 2014; Rodríguez-Álvarez, 2016) and are in keeping with our own experiments (see above) on the same type of quartz. 


\section{Cores and flakes from direct percussion core technology}

More than $60 \%$ of the ovoid and polyhedral pebbles/cobbles (between 40 and $110 \mathrm{~mm}$ ) of our corpus were broken by direct hard hammer percussion (Fig. 12, $n^{\circ} 1,3$, 4). This method seems to have been oriented towards the production of flakes (whole or broken).

Three types of cores are documented: (1) unipolar and unifacial cores (or chopper-cores, see below), with scars on the largest pebble surface or on the pebble edge with a cortical or a striking platform created by one removal, a fracture or a cortical surface (Fig. 12, 15A), (2) cores with two orthogonal flaking surfaces and alternate flaking which could be assimilated to the S.S.D.A flaking mode for the latter mode ( Ashton et al., 1992; Forestier, 1993) (Fig. 12, n4, Fig. 13), and (3) cores with centripetal removals (mainly unifacial) (Fig. 14).

\section{Figure 12.}

\section{Figure 13.}

The chaîne opératoire is rather short, both for cobbles and pebbles, generally resulting in the production of two to four flakes (or six at the most), using the unidirectional reduction of one to three orthogonal striking platforms. The results are thick flakes with oval or quadrangular contours, and they almost always bear cortical zones or cortex along one edge with at least one cutting edge (Table 1; Fig. 14, 18, 19 and 20). The reduction phase is longer when direct hard hammer percussion is used, as confirmed by smaller core morphologies (Fig. 15A and 15B). For unipolar/multipolar core technology and centripetal core technology, flakes with and without cortex are included. The graphs show that the dimensions are similar regardless of the core technology applied. The non-cortical flakes have the same average dimensions with lower variability, and are generally smaller than the cortical flakes. This is related to the morphology of the raw material. The core/flake ratio is less than 1 to 2 . For ovoid pebbles, the core/flake ratio is almost the same (1.5). For polyhedral pebbles, the ratio is 0.9 and there is a clear deficit of flakes.

Several explanations can be advanced to explain this deficit: (1) Most of the cores did not yield a lot of flakes or (2) Flakes were exported or moved to other areas of the site. The most likely explanations for these short reduction sequences are related to the characteristics of the raw material (the hardness of the raw material is not conducive to the exploitation of blocks of reduced dimensions), and to the final aim of production and raw material availability. As production seems to be very opportunistic and the main aim is to obtain thick flakes with at least one cutting edge, it was not necessary to continue the exploitation of cobbles until the raw material was depleted. Moreover, the presence of abundant raw materials near the site provided hominins with constant pebble availability. This consideration also provides information about the "timing of production": it is possible that knapping was carried out when required and not 
beforehand. If this is the case, production would be restricted to the number of "implements" necessary to perform a specific action.

Figure 14.

Figure 15.

Broken pebbles and pointed fragments or flakes from bipolar percussion core technology (split fractures)

The bipolar technique is the second most widespread method at the site. $39 \%$ of the ovoid and polyhedral pebbles (40 to $70 \mathrm{~mm}$ long) of our corpus were reduced using bipolar percussion, which produced a variety of flakes and debris with a relatively limited range of morphologies (half-pebbles or broken pebbles) (Fig. 12).

Regardless of the type of pebbles used or the reduction method employed, the chaine opératoire is always complete and short:

-When the pebble was struck perpendicularly to its longest axis, as was the case for most of the ovoid pebbles, the resulting product morphology is half-pebbles, typical of split fractures (i.e. Mourre and Jarry, 2004; Faivre et al., 2010; Boëda and Hou, 2011). These half-pebbles did not, in most cases, undergo further modification.

-Ovoid pebbles or pebbles with a flat transversal section were split in two ways. In the first case, percussion was localized near one of the edges. This results in two products characterized by pointed tips due to the shape of the breakage surfaces (two convergent parts). In the second case, percussion was applied to the middle of the surface, producing three products, which are again all characterized by a pointed tip, defined by the intersection of the breakage surfaces (Fig. 12).

\section{Heavy-duty tools and flake-tools}

Several groups of artefacts provide evidence of retouch or series of short removals in order to create a point or, more rarely, a new cutting edge (Table 1). We have added what we named chopper-cores to this group, which could also be described as pebble tools in some cases.

-Choppers-cores and/or pebble tools: 
Some pebbles and cobbles with scars on one surface can be characterized as chopper-cores or pebble tools

(Fig. 14). These artefacts have been differentiated from pebbles with a single isolated removal and cores by the cutting edge angle which is less than $70^{\circ}$, while it is more than $80^{\circ}$ for the unifacial cores (see Fig.12, 13). Two groups were identified:

1) A single cortical surface was used to detach two or three parallel flakes to create a more or less straight edge or a pointed edge. The main difference between this kind of production and unipolar debitage is that the removals produced are thinner and shorter and the resulting cutting edge does not show any denticulation. The removals were organized in order to delimit a continuous cutting edge. This cutting edge is in most cases parallel to the major axis of the cobble (Fig. 12, 13 and 14);

2) A break was used as a striking platform to detach a second flake, thereby creating a pointed tip (Fig. 13 for instance).

-Partial bifacial tool:

This artefact is unique and consists in partial shaping aimed at creating a convergent tool on a $70 \mathrm{~mm}$ long piece (Fig. 16). Both sides of the pebble were shaped by alternate striking. Several series of scars are visible (at least two or three), and the first are more invasive than the final removals on an abrupt edge on one surface creating two asymmetrical cutting edges. The cross-section is plano-convex and removals are less frequent on the flatter surface despite being invasive. Cortical patches remain on the two faces and the selected pebbles seem to have already been asymmetrical (preform). Shaping follows the natural form of the pebble. The distal part is abrupt and could have been broken. Owing to the density and organization of the removals, this artefact cannot be considered as a core or a geofact. It has been considered as a peripheral chopping-tool by the slight convergence of the two edges, perhaps made by additional series of removals, or a partial bifacial tool (genuine Large Cutting Tool).

\section{Figure 16.}

\section{Suppl. 4.}

-Flake-tools or retouched debris:

A total of 43 retouched flakes and debris were identified among the whole series (Fig. 14, $\mathrm{n}^{\circ} 7$ and Fig. 18, 19). Blanks were not selected for retouch because of their size as they are of disparate dimensions, with lengths comprised between 20 and $100 \mathrm{~mm}$, in keeping with the general series of flakes and debris (Fig. 18). Also, from a technological point of view, the retouched blanks (composed of $90 \%$ flakes) are not issued from a specific debitage method when this is possible to determine. In all cases, the flakes bear some cortex, generally in a lateral position.

The aim of the retouch seems to be the slight modification or re-sharpening of the cutting edge. Retouch is marginal or more invasive, from semi-abrupt to abrupt, and we can distinguish a regular retouched edge 
(considered as a side-scraper, Fig. $14 \mathrm{n}^{\circ} 7$ ) and a denticulated edge (considered as a denticulate, Fig. $14, \mathrm{n}^{\circ} 5$ and Fig. $\left.17, n^{\circ} 4\right)$. The retouched zone is generally continuous, situated on the longer edge, and cannot be due to natural crushing owing to its size and regularity, even for the denticulated edge. The retouch is always direct (on the convex face).

\section{Figure 17.}

Figure 18.

Figure 19.

\section{Discussion}

\section{Pont-de-Lavaud: short chaines opératoires by direct percussion and bipolar technology}

The Pont-de-Lavaud lithic assemblage dated to $1.1 \mathrm{Ma}$ is characterized by short chaînes opératoires on local quartz aimed at producing half-pebbles, fragments of pebbles and flakes. Bipolar and direct percussion on pebbles produce pointed half-pebbles and pointed pebble fragments, raising questions as to the significance of such quantities of pointed end-products (intentional or accidental). The core technologies and techniques used (direct percussion and the bipolar technique) were heavily influenced by the raw material (morphology and physical characteristics), as quartz is hard to flake using direct percussion, as demonstrated by our experiments and the petrographic characteristics of the quartz used in situ. These factors probably account for the high frequency of bipolar reduction on anvils in this assemblage.

It also bears emphasizing that raw material nodules were never very extensively reduced. Quartz was very abundant near the site, either as pebbles/cobbles or vein deposits.

Shaping is a secondary reduction sequence. It is mainly represented by chopper-cores and unifacial pebble tools. Retouched flakes are rare (3.9\%) and, when present, they are mainly lightly retouched side-scrapers, notches or denticulates, always modified on their longest edge. Note also the presence of a single tool with evidence of partial bifacial shaping.

\section{Common technological behaviors in Europe at around $1 \mathrm{Ma}$}

From a general point of view, if we compare the technological characteristics of the Pont-de-Lavaud lithic assemblage to other South and North European Early Palaeolithic series dated to around $1 \mathrm{Ma}$, for instance the artefacts of Sima del Elefante (Rosas et al., 2001; Carbonell and Rodriguez ., 2006; Parés et al., 2006; Lombera-Hermida t al., 2016), Barranco Léon and Fuente Nueva 3 in Spain (Barsky et al., 2010; ToroMoyano et al., 2003, 2009), Pirro Nord in Italy (Arzarello et al., 2006, 2010, 2012, 2015), Monte Poggiolo (Peretto et al., 1998; Peretto, 2006) and Le Vallonnet in France (Lumley et al., 1988; Michel et al., 2017), or 
Happisburgh 3 and Pakefield in Great-Britain (Parfitt et al., 2005, 2010), we observe first of all consistent technical behavior characteristic of the earliest lithic skills, and secondly, strategies strongly influenced by raw materials. In all these sites, the raw materials were collected from a secondary position very close to the site.

In all the sites, the main debitage method is (1) "opportunistic", poorly structured, highly influenced by the geometry of the stone and (2) generally associated with some centripetal cores.

Generally, the reduction sequences are short and raw materials are rarely fully depleted. Percussion is either direct or bipolar. In Sima del Elefante, Pirro Nord, Le Vallonnet and the British sites, bipolar percussion was not used. If we expand our comparison to earlier sites, such as Dmanisi in South Caucasus, dated to $1.8 \mathrm{Ma}$, providing the earliest evidence of "Out of Africa" expansion, bipolar percussion is not used there either (Mgeladze et al., 2011). This may possibly be related to the reduced number of artefacts for some series but above all to the raw materials, which are siliceous rocks, volcanic rocks or limestone.

The heavy-duty component is present in Pont-de-Lavaud, with chopper-cores and unifacial pebble tools, and in the other sites where flint is not the only raw material used. In Europe, only the Italian sites of Pirro Nord and Cà Belvedere di Monte-Poggiolo do not include a shaping component, probably because flint is the only exploited raw material.

The presence of some retouched products at Pont-de-Lavaud and the sites of Orce and the Italian area is a singular feature. They account for less than $3 \%$ of the lithic assemblage. Retouch is generally located on the longest edge and covers the whole edge.

At $1 \mathrm{Ma}$, among the earliest European sites, the site of Cà Belvedere di Monte Poggiolo (Peretto et al., 1998; Peretto, 2006; Arzarello and Peretto, 2010) bears the most similarities with Pont-de-Lavaud despite the use of different raw materials, but with a similar initial morphology. Both these sites are located on the raw material deposit and local ovoid pebbles/cobbles were preferentially selected. They were worked by bipolar percussion on an anvil or by direct percussion, regardless of the stone type: flint for Monte Poggiolo and quartz for Pont-de-Lavaud. In both sites the reduction sequences are short and primarily "opportunistic", and unipolar debitage from one or more orthogonal striking platforms is dominant. Once again, raw material morphology is likely to have influenced the presence of retouch and the shaping process in Pont-de-Lavaud, both of which are absent in Cà Belvedere di Monte Poggiolo. The poor cutting qualities of some types of quartz may have required the production or resharpening of thick and strong cutting edges using unifacial or bifacial shaping.

\section{Common strategies on quartz assemblages at $1 \mathrm{Ma}$ in Europe}


The few European sites using quartz at 1 Ma share common trends with our Pont-de-Lavaud corpus (Table 2). At Sima del Elefante (Atapuerca), the earliest hominin activity is documented in TE9 (1.2-1.1 Ma; Carbonell and Rodriguez, 2006), with a small series of Neogene and Cretaceous chert artefacts. Knapping was simple and produced flakes using the unidirectional method. The TD 6 (0.8 Ma) levels yielded quartz assemblages on local raw materials (Lombera-Hermida et al., 2016). In TD6, the largest series indicates the selective use of bipolar percussion on quartz, whereas angular blocks or nodules of chert/flint were flaked differently (using multidirectional, orthogonal and centripetal methods) (Carbonell et al., 1999). Flint flakes are the only retouched pieces.

At Vallparadis (0.8 Ma), $70 \%$ of the artefacts are in quartz and present short reduction sequences, which are either simple or orthogonal, with the use of bipolar percussion (Martinez et al., 2010; Garcia et al., 2012, 2013; Rodríguez-Álvarez, 2016). Note also the presence of pointed products at this site.

\section{Sporadic onset of a bifacial technology?}

If we consider that the partial bifacial artefact is not a chopping-tool but a genuine Large Cutting tool, the discovery of this bifacial piece at Pont-de-Lavaud raises the hypothesis of a sporadic emergence of bifacial technology in core-and-flake traditions, as observed in a few early sites in Europe but with no real development of the technique, before the first clear evidence of bifacial technology (la Noira, Moncel et al., $2013,2015)$. In some sites, we observe one or two pieces with the partial bifacial management of two convergent edges and sometimes a pointed or round tip.

The sites of Pradayrol (900 ka), Soleilhac (500-700 ka), assemblages from the Upper Roussillon and Rhône terraces in France or the site of Bogatyri (1.4-1.1 Ma) in Russia may record some attempts at bifacially worked pieces in parallel with the arrival of external bifacial technologies (Bourdier, 1958; Tavoso, 1986; Bracco, 1991; Shchelinsky et al., 2010; Guadelli et al., 2012). Some shaped tools are described on basalt and granite at Soleilhac, made by some removals slightly modifying a large flake (Bonifay et al., 1976). Similarly, at Pradayrol, a limited zone of a broken slab was bifacially shaped by non-invasive removals. La Boella, with two bifacial pieces, dated to around $900 \mathrm{ka}$, is currently the best example to discuss the early arrival of bifacial technology in Europe, either introduced on a pre-existing foundation or as a local development (Vallverdu et al. 2014). However, the two pieces at La Boella differ from the partial bifacial tool of Pont-deLavaud. In pit 1, level 2, a pick made on a split schist cobble was shaped by some deep and large removals on the half-cobble, creating a pointed tip, and secondary small removals, creating an abrupt cutting edge on one side. A schist cleaver is also described in level 2 at the EF site, which is partially bifacial on a split cobble. The younger site of Notarchirico, at around $670 \mathrm{ka}$, can no longer be considered as evidence of the local origin of bifacial technology since some bifaces with bifacial management of the volume occur at this site (Piperno ed., 1999; Santagata, 2016, and personal observation), despite the numerous bifacial and pointed pebble-tools made by small series of deep removals. 
In some ways, this problem parallels the issue in East African assemblages described as Developed Oldowan or Early Acheulean, where it is still unclear whether there are tangible links or a rupture over time (Torre et al., 2005, 2008, 2011). A local European origin for bifacial working seems unlikely given that there is currently little evidence of the in situ development of partial bifacial working (Moncel et al., 2015). The partial bifacial tool at Pont-de-Lavaud could provide evidence at $1 \mathrm{Ma}$ of attempts at bifacially worked pieces among a core-and-flake industry.

\section{Conclusion}

The comparison between our experiments and the description of the quartz artefacts on pebbles enables us to consider the quartz artefacts found at Pont-de-Lavaud as evidence of anthropogenic action. The site is consequently one of the earliest representative European and French sites, not only on account of its age of 1.1 Ma, but also because it is the largest known lithic assemblage. It provides a good overview of the technical behavior and strategies adopted by hominins exploiting quartz during the first wave of European expansion.

The study of the site of Pont-de-Lavaud, in parallel with our experiments, confirms that the bipolar technique was an expedient debitage, well adapted to rounded quartz pebbles, but also a regularly used method, as it was also applied to polyhedral quartz pebbles. This technique was effective for initiating small and ovoid/polyhedral pebble breakage and producing fragments and flakes, as demonstrated by other technological experiments Lombera-Hermida de et al., 2016). It was not only used for a specific geometry of quartz blanks but was applied to all the categories of quartz stones available in the surroundings. It is consequently clearly part of the technical skills of European hominins at $1.1 \mathrm{Ma}$ and was a flexible technique indicating a high degree of hominin cognition and the ability to adapt to various raw materials of mixed quality.

The presence of a small set of retouched flakes and a partial bifacial piece ("proto-biface") indicates the ability of hominins to develop longer processes on quartz if necessary.

The choice of bipolar debitage on quartz is frequently attributed to raw material constraints (in terms of initial morphology and petrology) and is considered to require less skill than freehand percussion (Barham, 1987; Shott, 1999; Stout and Semaw, 2005; Tallavaara et al., 2010; Diez-Martin et al., 2011; Braun, 2012). However, the bipolar technique indicates the ability of hominins to find technical solutions for breaking ovoid quartz nodules that are difficult to break with freehand percussion, and to produce pieces suitable for use (Peña de la, 2015; Hiscok, 2015; Pargeter and Duke, 2015; Rodríguez-Álvarez, 2016; Li Hao et al., 2017).

Recent experiments at Olduvai (BK and FLK-North sites, Gurtov and Eren, 2014) confirm that the bipolar technique does not produce specific flakes in terms of cutting edge length or other significant features 
(Gurtov et al., 2015). Products are characterized by the variability of the implements commonly produced by Mode 1-behavior hominins.

The Ugandan site of Nyabusosi 18, dated to $1.5 \mathrm{Ma}$, shows that in some cases quartz may provide a complex and well-organized core technology. This site yielded centripetal cores and a lot of flakes without cortex, suggesting long reduction sequences (Texier, 1995). Moreover, use wear analyses performed on quartz and quartzite Oldowan artefacts found at Kanjera South (Kenya) indicate that these types of stones were operative (Lemorini et al., 2014). Likewise, the lithic material from Bizat Ruhama in Israel indicates that the bipolar technique can also be applied to small flint pebbles, confirming the flexibility of Oldowan hominins (Zaidner, 2013).

Pont-de-Lavaud presents common features with the Early European sites and indicates common technical behaviors at $1 \mathrm{Ma}$ both in the South, the North and the intermediary area of the Center of France. Reduction processes are short, flake-tools are sparse and the core technology clearly reflects adaptation to raw material forms and types. At Pont-de-Lavaud, faunal remains were not preserved and we cannot relate the strategies observed to a specific type of occupation or activity. We cannot explain why hominins settled at this place and used such quantities of quartz, except if we consider that they used the main stones available at the site. The diversity of the technological strategies possibly suggests either different needs or traditions. Pont-de-Lavaud confirms the ability of early hominins to exploit stones of varying quality, including those considered to be of bad quality, and to adapt technology to the raw material in areas located beyond the $45^{\circ}$ North parallel where siliceous rocks are available. The high number of artefacts suggests recurrent occupations and the exploitation of raw materials collected on the slope. Huge quantities of quartz were used and the technical strategies observed at the site correspond well to behaviors throughout Europe around $1 \mathrm{Ma}$, based on core-and-flake technologies with some attempts at bifacial working, although there may not be any connection with the onset of bifacial technology at around $700 \mathrm{ka}$.

Finally, the Pont-de-Lavaud site attests hominid adaptation to northern latitudes. However, hominids came when the climate was favorable as shown by the palynological record, which points to a temperate climate with dense forest. Hominids were present during an interglacial and at the beginning of the following glacial event. Compared to the other contemporaneous sites and the earliest evidence from Dmanisi, the environmental context was different and indicates the ability of 1 Ma-hominids to adapt to different contexts.

\section{Acknowledgements}

The fieldwork and studies were financially supported by the French Ministry of Culture and the Centre Région (France). Many thanks to Robert Gageonnet, Jean-Claude Jouanneau, Ingénieur civil des Mînes, Laboratoire régional des Ponts et Chaussées, Blois (Centre), for the geological and petrological analyses, 
Pascal Alilaire, Ingénieur, French Ministry of Culture, regional direction, Orleans (Centre) for contributing to experiments and Philippe Touchard, journalist (Blois, Centre) for the photographs of experiments.

A particular thank to the two reviewers and the editor for their comments that help us enhancing the paper. The English version was edited by Louise Byrne (official translator).

\section{References}

Ashton, N.M., Cook, J., Lewis, S.G., Rose, J., (Eds), 1992. High Lodge: Excavations by G. de G. Sieveking 196268 and J. Cook 1988. British Museum Press, London.

Arzarello, M., Marcollini, F., Pavia, G., Pavia, M., Petronio, C., Petrucci, M., Rook L., Sardella, R., 2006. Evidence of earliest human occurrence in Europe: the site of Perro Nord (Southern Italy), Naturwissenschaften 94,107-112.

Arzarello M., Moncel M.H., Peretto C., 2015. The Pirro Nord site (Apricena, FG, Southern Italy) in the context of the first European peopling: convergences and divergences. Quaternary International. Vol 389: 255-263.

Arzarello, M., PerettoC. , 2010. Out of Africa: The first evidence of Italian peninsula occupation. Quat. Int. 223-224, 65-70.

Arzarello, M., Pavia, G., Peretto, C., Petronio, C., Sardella, R., 2012. Evidence of an Early Pleistocene hominin presence at Pirro Nord (Apricena, Foggia, southern Italy): P13 site. Quat. Int. 267, 56-61.

Bahain, J.J., Falguères, C., Laurent, M., Voinchet,P., Dolo, J.M., Antoine, P., Tuffreau, A.,2007. ESR chronology of the Somme River Terrace system and first human settlements in Northern France. Quaternary Geochronology 2 356-362

Barham, L., 1987. The bipolar technique in Southern Africa: a replication experiment. The South African Archaeological Bulletin 42, 45-50.

Barsky, D., Celiberti, V., Cauche, D., Grégoire, S., Lebègue, F., de Lumley, H., Toro-Moyano, I., 2010. Raw material discernment and technological aspects of the Barranco León and Fuente Nueva 3 stone assemblages (Orce southern Spain). Quat. Int. Hum. Expans. Eurasia Favouring Limiting Factors 223-224, 201-219.

Barsky, D., Chapon-Sao, C., Bahain, J.-J., Beyene, Y., Cauche, D., Celiberti, V., Desclaux, E., de Lumley, H., de Lumley, M.-A., Marchal, F., Moullé, P.-E., Pleurdeau, D., 2011. The Early Oldowan Stone-Tool Assemblage from Fejej FJ-1A, Ethiopia. Journal of African Archaeology 9 (2), 207-224.

Barsky, D., Vergès, J. M., Sala, R., Menéndez, L., Toro-Moyano, I. 2015. Limestone percussion tools from the late Early Pleistocene sites of Barranco León and Fuente Nueva 3 (Orce, Spain). Phil. Trans. R. Soc. B 370 (1682), 20140352.

Boëda, E., Hou, Ya-Mei 2011. Etude du site de Longgupo. Synthèse. L'Anthropologie, Paris 115, 176-196.

Bonifay, E., Tiercelin, J.-J., Bonifay, M.F., Panattoni, R. 1976. Soleilhac (Blanzac, Haute-Loire), nouveau site préhistorique du début du Pléistocène moyen, Bulletin de la Société préhistorique française, 73, p. 293-304.

Bouloton, J., 1974. Etude géologique de la région d'Aigurande (NW du Massif central français). Lithostratigraphie, structure et pétrographie de la série métamorphique. Thèse de troisième cycle, Clermont-Ferrand, $166 \mathrm{p}$.

Bourdier, F., 1958. Le bassin du Rhône au Quaternaire. Géologie et Préhistoire, Université de Paris, thèse de doctorat. 
Bosinsky, G., Brunnacker, K ., Lanser, K. P., Stephan, S., Urban, B., Würges, B., 1980. Altpaläolithische Funde von Kärlich, Kreis Mayenz, Koblenz, Arch. Korrez 10, 295-314.

Bosinski, G., 2006. Les premiers peuplements de l'Europe Centrale et de l'Est, Colloque " Climats-CulturesSociétés aux temps préhistoriques. De l'apparition des Hominidés jusqu'au Néolithique ", Palevol 5, n¹-2, 311-319.

Bracco, J-P., 1991. Typologie, technologie et matières premières des industries du très ancien Paléolithique en Velay (Massif central, France) premiers résultats. In: Bonifay E., Vandermeersch B. (eds) Les premiers peuplements européens. CTHS - Congrès National des Sociétés savantes, Paris, pp 93-100.

Braun, D., 2012. What does Oldowan technology represent in terms of hominin behavior? In: DominguezRodrigo, M. (Ed.), Stone Tools and Fossil Bones: Debates in the Archaeology of Human Origins. Cambridge University Press, Cambridge, 222-244.

Cailleux, A., 1958. Des filons aux galets de quartz (glacier de Saint-Sorlin). Revue de Géographie alpine. 48, $3,415-421$.

Cancellieri, E., Coppola, E., D’Angelo, R., Di Leo, R., Rinaldi, M.F., Rossi D., 2001. La tecnica di schegggiatura bipolare applicata ai ciottoli. In "The world of Elephants", Rome, 23-26.

Cande, S. C., Kent, D.V., 1995. Revised calbration of the geomagnetic polarity timescale for the Late Cretaceous and Cenozoic. Journal of Physical Research, 100, 6.093- 6.095.

Carbonell, E., Garcia-Anton, M.D., Mallol, C., Mosquera, M., Ollé, A., Rodríguez, X.P., Sahnouni, M., Sala, R., Vergès, J.M., 1999. The TD6 lithic industry from Grand Dolina, Atapuerca (Burgos, Spain) production and use, J. Hum.Evol. 37, 653-693.

Carbonell, E., Rodriguez P., X., 2006. The first human settlement of Mediterranean Europe. C. R. Palevol 5, 291-298.

Carbonell, E., Bermudez de Castro, J., Parès, J., Perez-Gonzalez, A., Cuenca-Bescos, G., Ollé, A., Mosquera, M., Huguet, R., van der Made, J., Rosas, A., Sala, R., Vallverdú, J., García, N., Granger, D., Martinón-Torres, M., Rodriguez, X., Stock, G., Vergès, J., Allue, E., Burjachs, F., Cacerès, I., Canals, A., Benito, A., Díez, C., Lozano, C., Mateos, A., Navazo, M., Rodríguez, J., Rosell, J., Arsuaga, J. L., 2008. The first hominin of Europe. Nature 452, 456-470.

Carbonell, E., Ramos, R.S., Rodríguez, X.P., Mosquera, M., Ollé, A., Vergès, J.M., Martinez-Navarro, B., de Castro, J.M.., 2010. Early hominid dispersals: a technological hypothesis for Out of Africa. Quaternary International 223, 36-44.

Carrión, J.S., Rose, J., Stringer, C., 2011. Early Human Evolution in the Western Palaearctic: Ecological Scenarios. Quaternary Science Reviews 30, 11-12, 1281-1295.

Chenevoy, M. 1968. Les gneiss amygdalaires du Massif central français. Revue de Géographie Physique et Dynamique, (2), X, 113-122.

Cojan, I., Renard, M., 2006. Mise en place des sédiments clastiques. In: Sédimentologie, chap. 3. 92-151. Dunod, Paris.

Cohen-Jullien, M., Quenardel, J.M., Freytet, P., Lerouge, G., Rolin, P., Schmitt P., Constans, J. , Vautelle, C., 1989. Carte géologique de la France à $1 / 50$ 000, feuille Dun-le-Palestel (616). Bureau de Recherches géologiques et minières, Orléans-la Source. 
Cohen-Jullien, M., Quenardel, J.M., Lerouge, G., Lorenz, J., Lorenz, C., Macaire, J.J., Freytet, P., Maget, P. , Debrand-Passard, S. 1998. Carte géologique de la France à 1/ 50 000, feuille Argenton-sur-Creuse (593). Bureau de Recherches géologiques et minières, Orléans-la Source.

Commont, V. 1909b. Silex présentant les apparences de la taille intentionnelle à la base de l'Eocène. Annales de la Société Géologique du Nord, 38, 462-479.

Crabtree, D.E. 1972. An introduction to flint working. Pocatello: Occasonal Papers oh the IUdaho Sytate University Museum.

Curtoni, R. 1996. Experimentado con bipolares: indicadores e implicanciones arqueológicas. Relaciones de la Sociedad Argentina deAntropologia, 21, 187-214.

Cuenca-Bescos, G., Melero-Rubio, M., Rofes, J., Martinez, I., Arsuaga, J.L., Blain, H-A., Lôpez-Garcia, J.M., Carbonell, E., Bermúdez de Castro, J.M., 2011. The Early-Middle Pleistocene environmental and climatic Change and the Human Expansion in Western Europe: a case study with small vertebrates (Gran Dolina, Atapuerca, Spain). Journal of Human Evolution 60, 4, 481-491.

Delagnes, A., Roche, H., 2005. Late Pliocene hominid knapping skills: The Case of Lokalalei 2C, West Turkana, Kenya, J. Hum.Evol. 48, 435-472.

Delagnes, A., Boisserie, J-R., Beyene, Y., Chuniaud, K., Guillemot, C., Schuster, M., 2011. Archaeological investigations in the Lower Omo Valley (Shungura Deposit, Ethiopia): New data and perspectives. J. Hum.Evol, 61(2), 215-222.

de Lombera-Hermida, A., Rodríguez-Álvarez, X.P., Peña, L., Sala-Ramos, R., Despriée, J., Moncel, M.H., Gourcimault, G., Voinchet, P. and Falguères, C., 2016. The lithic assemblage from Pont-de-Lavaud (Indre, France) and the role of the bipolar-on-anvil technique in the Lower and Early Middle Pleistocene technology. Journal of Anthropological Archaeology 41, 59-184.

Despriée, J., Villes , A., \& Richard, G. (1983) - Informations archéologiques de la région Centre. GalliaPréhistoire, 26, 2, 249-282. Ed. C.N.R.S., Paris.

Despriée, J., Gageonnet, R., 2003. La très haute nappe alluviale d'âge pleistocène inférieur de la vallée de la Creuse à Eguzon (Indre) : figures de cryoturbation, habitats préhistoriques et datations absolues. Bulletin de la Société géologique de France, 174, 4, 383-400.

Despriée, J., Gageonnet, R., Voinchet, P., Bahain, J.J., Falguères, C., Duvialard, J., Varache, F., 2004. Pleistocene fluvial systems of the Creuse river (Middle Loire Basin - Centre Region, France). Quaternaire, $15,1-2,45-56$.

Despriée, J., Gageonnet, R., Voinchet, P., Bahain, J.J., Falguères, C., Varache, F., Courcimault, G., Dolo, J.M., 2006. Une occupation humaine au Pléistocène inférieur sur la bordure nord du Massif Central. C.R. Palévol, $5,821-828$

Despriée, J., Voinchet, P., Tissoux, H., Moncel, M.H., Arzarello, M., Robin, S., Bahain, J.J., Falguères, C., Courcimault, G., Dépont, J., Gageonnet, R., Marquer, L., Messager, E., Abdessadok, S., Puaud, S. (2010) Lower and middle Pleistocene human settlements in the Middle Loire River Basin, Centre Region, France. Quat. Int. 223-224, 345-35 
Despriée, J. , Voinchet, P., Tissoux, H., Bahain, J.-J., Falgueres, C., Courcimault, G., Depont, J., Moncel, M.-H., Robin, S., Arzarello, M., Sala, R., Marquer, L., Messager, E., Puaud, S., Abdessadok, S., 2011. Lower and Middle Pleistocene human settlements recorded in fluvial deposits of the middle Loire River Basin, Centre Region, France. Quat. Sc. Rev. 30 (11-12), 1474-1485.

Diez-Martín, F., Sánchez, P., Domínguez-Rodrigo, M., Mabulla, A,, Barba, R., 2009. Were Olduvai Hominins making butchering tools or battering tools? Analysis of a recently excavated lithic assemblage from BK (Bed II, Olduvai Gorge, Tanzania). J. Anth. Arch. 28(3), 274-289.

Diez-Martin, F., Yustos, P., Dominguez-Rodrigo, M., Prendergast, M., 2011. An experimental study of bipolar and freehand knapping of Naibor Soit Quartz from Olduvai Gorge (Tanzania). American Antiquity 76, 690 708.

Dill, H.G., kKmper, E., 1990. Crystallographic and chemical variations during pyritization in the Upper Barremian and Lower Aptian dark claystone from the Lower Saxonian Basin (NW Germany). Sedimentology $37,427-443$.

Faivre, J-P., Geneste, J.-M., Turq A., 2010. La fracturation en split, une technique de production dans I'industrie lithique des Tares (Sourzac, Dordogne), Entre le marteau et l'enclume, Paléo, 1-11.

Falguères, C., Bahain, J-J., Yokoyama, Y., Arsuaga, J.L., Bermudez de Castro, J.M., Carbonell, E., Bischoff J.L., Dolo, J-M., 1999. Earliest humans in Europe ; the age of TD6 Gran Dolina, Atapuerca, Spain, J. Hum. Evol. 37, (3-4), 343-353.

Falguères, C.,Voinchet, P., Bahain, J.J., 2002. ESR Dating as a Contributor to the Chronology of the Earliest Humans in Europe. Advances in ESR Applications, 18, 17-26.

Falguères, C., 2003. ESR dating and the human evolution: contribution to the chronology of the earliest humans in Europe. Quaternary Geochronology (Quat. Sc. Rev.) 22, 1345-1351.

Forestier, H., 1993. Le Clactonien: Mise en application d'une nouvelle méthode de débitage s'inscrivant dans la variabilité des systèmes de production lithique du Paléolithique ancien. Paleo 5, 53-82.

Garcia, J., Martinez, K., Carbonell, E,, Agusti, J., Burjachs, F., 2012. Defending the early human occupation of Vallparadis (Barcelona, Iberian Peninsula): A reply to. J. Hum.Evol. 63(3), 568-575.

Garcia, J., Martinez, K., Carbonell, E., 2013. The Early Pleistocene stone tools from Vallparadis (Barcelona, Spain): Rethinking the European Mode 1. Quat. Int. 316(0), 94-114.

Garon, H., 2014. Datation par ESR des sédiments quaternaires de la Creuse : bassin d'Argenton-su-Creuse. Mémoire de Master du Muséum national d'Histoire naturelle, Paris, 100 p.

Garon, H., Voinchet, P., Bahain, J.J., Despriée, J., Courcimault, G., ,Tissoux, H. Falguères, C. 2017. Datation ESR de quartz fluviatiles :nouvelles données chronologiques pour le secteur intermédiaire de la vallée de la Creuse (Indre, région Centre, France). Quaternaire, 28 (1), 73-85.

Guadelli, J.-L., Turq, A., Seronie-Vivien, R., 2012. Le site de Pradayrol à Caniac-du-Causse (Lot). In: Turq A., Airvaux J., Despriée J., Texier P-J. (eds.), La conquête de l'Ouest Il y a un million d'années en Europe. Musée des Eyzies. Maison de l'Histoire de France, pp. 136-137.

Gurtov, AN., Eren, MI., 2014. Lower Paleolithic bipolar reduction and hominin selection of quartz at Olduvai Gorge, Tanzania: What's the connection? Quat. Int. 322-323, 285-291. 
Gurtov, AN., Buchanan, B., Eren, MI., 2015. "Dissecting" quartzite and basalt bipolar flake shape: a morphometric comparison of experimental replications from Olduvai, Tanzania, Lithic Technology.

Hayden, B. 2015. Insights into early lithic technologies from ethnography. Phil. Trans. R. Soc. B, 370(1682), 20140356.

Hiscock, P., 2015. Dynamics of knapping with bipolar techniques: modelling transitions and the implications of variability, Lithic Technology.

Leakey, M., 1971. Olduvai Gorge Volume III: Excavation in Bed I and II, 1960-1963. Cambridge University Press, Cambridge.

Leakey, M., Roe, D. 1994. Olduvai Gorge: Volume 5, Excavations in Beds III, IV and the Masek Beds (Vol. 5). Cambridge University Press.

Lemorini, C., Plummer, T. W., Braun, D.R., Crittenden, A.N., Ditchfield, P.W., Bishop, L.C., Hertel, F., Oliver, J. S., Marlowe, F.W., Schoeninger, M.J., Potts, R., 2014. Old stones' song: Use-wear experiments and analysis of the Oldowan quartz and quartzite assemblage from Kanjera South (Kenya). Journal of Human Evolution $72,10-25$.

Li, F., 2016. An experimental study of bipolar reduction at Zhoukoudian locality 1, north China. Quaternary International, 400, 23-29.

Li, Hao, Li, C., Sherwood, N. L., \& Kuman, K., 2017. Experimental flaking in the Danjiangkou Reservoir Region (central China): A rare case of bipolar blanks in the Acheulean. Journal of Archaeological Science: Reports 13, 26-35

Lisieki L.E., Raymo, M.E. 2005. A Pliocene-Pleistocene stack of 5è globally distributed benthic $\delta 18$ o records. Paleoceanography and paleoclimatology, 20(2), PA 1003, 17 p.

Lombera-Hermida, de A., Rodríguez, X.P., Fábregas, R., Moncel, M-H., 2011. La gestion du quartz au Pléistocène moyen et superieur. Trois exemples d'Europe meridionale. L'Anthrolopogie 115-2, 294-331.

Lombera-Hermida, de A., Bargallo, A., Terradillos-Bernal, M., Huguet, R., Vallverdú, J., García-Anton, M-D., Mosquera, M., Ollé, A., Sala, R., Carbonell, E., Rodríguez-Alvarez, X-P., 2015. The lithic industry of Sima del Elefante (Atapuerca, Burgos, Spain) in the context of Early and Middle Pleistocene technology in Europe. Journal of Human Evolution 82, 95-106.

Lombera-Hermida, de A., Rodríguez-Álvarez, X. P., Peña, L., Sala-Ramos, R., Despriée, J., Moncel, M. H., Courcimault, G., Voinchet, P., Falguères, C. 2016. The lithic assemblage from Pont-de-Lavaud (Indre, France) and the role of the bipolar-on-anvil technique in the Lower and Early Middle Pleistocene technology. Journal of Anthropological Archaeology, 41, 159-184.

Lordkipanidze, D., Jashashvili, T., Vekua, A., Ponce de Leòn, M.S., Zollikofer, P.E., Rightmire, G.P. et al., 2007. Postcranial evidence from early Homo from Dmanisi, Georgia. Nature 449, 305-310.

Lumley, H. De, Fournier, A., Krzepkowska, J., Echassoux, A., 1988. L'industrie du Pléistocène inférieur de la grotte du Vallonnet, Roquebrune-Cap-Martin, Alpes-Maritimes. L’Anthropologie 92, 501-614.

MacDonald, K., Martinez-Torres, M., Dennell, RW., Bermudez de Castro, JM., 2012. Discontinuity in the record for hominin occupation in south-western Europe: Implications for occupation of the middle latitudes of Europe. Quaternary International 271, 84-97. 
Marquer, L., Messager, E., Renault-Miskovsky, J., Despriee, J., Gageonnet, R., Voinchet, P., Bahain, J-J., Falguères, C., 2011. Paléoovégétation du site à hominidés de Pont-de-Lavaud, Pléistocène inférieur, région Centre, France. Quaternaire 22(3), 187-200

Martinez-Navarro, B., Turq, A., Agusti Ballester, J., Oms, O., 1997. Fuente Nueva 3 (Orce, Grananda, Spain) and the first human occupation of Europe, Journal of Human Evolution 33, 611-620.

Martínez, K., Garcia, J., Burjachs, F., YII, R., \& Carbonell, E., 2014. Early human occupation of Iberia: the chronological and palaeoclimatic inferences from Vallparadís (Barcelona, Spain). Quat. Sc. Rev. 85, 136146.

Martinez, K., Garcia, J., Carbonell, E., Agusti, J., Bahain, J-J., Blain, H.-A., Burjachs, F., Caceres, I., Duval, M., Falguères, C., Gomez, M., Huguet R., 2010. A new Lower Pleistocene archaeological site in Europe (Vallparadis, Barcelona, Spain). PNAS 107(13), 5762-5767.

Messager, E., Lebreton, V., Marquer, L., Russo-Ermolli, E., Orain, R., Renault-Miskovsky, J., Lordkipanidze, D., Despriée, J., Peretto, C., Arzarello, M. 2011. Palaeoenvironments of early hominins in temperate and Mediterranean Eurasia: new palaeobotanical data from Palaeolithic key-sites and synchronous natural sequences. Quaternary Sciences Review 30(11-12), 1439-1447.

Mgeladze, A., Lordkipanidze, D., Moncel, M.-H., Despriee, J., Chagelishvili, R., Nioradze, M., Nioradze, G., 2011. Hominin occupations at the Dmanisi site, Georgia, Southern Caucasus: raw materials and technical behaviors of Europe's first hominins. J. Hum. Evol. 60, 571-596.

Michel V., Chuan-Chou Shen, Woodhead J., Hsun-Ming Hu, Chung-Che Wu, Moullé P-E., Khatib S., Cauche D., Moncel M-H., Valensi P., Yu-Min Chou, Gallet S., Echassoux A., Orange F., de Lumley H. 2017 - The earliest hominins in Southern Europe: A new chronological framework for Vallonnet Cave. Scient. Rep. 7 : 10074 DOI:10.1038/s41598-017-10178-4.

Mithen, S., Reed, M., 2002. Stepping out: a computer simulation of hominid dispersal from Africa, J. Hum. Evol. 43, 433-426.

Moncel M-H., J.Despriée, P.Voinchet, H.Tissoux, D.Moreno, J-J.Bahain, G.Courcimault, C. Falguères, 2013 Early evidence of Acheulean settlement in north-western Europe - la Noira site, a 700000 year-old occupation in the Center of France, Plos One, November 2013, Volume 8, Issue 11, e75529.

Moncel M-H., J. Despriée, P.Voinchet, G.Courcimault, B. Hardy, J-J.Bahain, S. Puaud, X.Gallet, C.Falguères, 2016- The Acheulean workshop of la Noira (France, $650 \mathrm{ka}$ ) in the European technological context, Special issue First European, Quaternary International, 393, 112-136.

Mosquera M, Ollé A, Rodriguez X.P., 2013. From Atapuerca to Europe: Tracing the earliest peopling of Europe. Quaternary International 295,130-137.

Mourre, V., 1996. Les industries en quartz au Paléolithique : terminologie, méthodologie et technologie. Paléo 8:205-223

Mourre, V., Jarry, M., 2004. État du domaine et bibliographie de référence. In: Mourre V., Jarry, M., eds., Entre le marteau et l'enclume. Table ronde sur la percussion directe au percuteur dur et la diversité de ses modalités d'application. Résumés des communications, Toulouse, p. 2-10.

Niang, K., 2014. Le Mode 1 en Italie entre hétérognéité et géofacts : le cas de la redéfinition technologique de l'industrie lithique du site de Bel Poggio L'Anthropologie 118 (4), 391-407.

Obermaier, H. 1012. Der Mensch der Vorzeit. Allgemeine Verlags-Gesellschaft, Berlin, München, Wien, Kapitel 9, 392-400. 
Parés, J.M., Pérez-Gonzàlez, A., Rosas, A., Benito, A., Bermùdez de Castro, J.M., Carbonell, E., Huguet, R., 2006. Matuyama-age lithich tools from the Sima del Elefante site, Atapuerca (northenSpain). J. Hum. Evol. $50,163-169$.

Parfitt, S.A., Ashton N.M., Lewis S.G., Abel R.L., Russell Cooper G., Field M.H., Gale R., Hoare P. G., Larkin N. R.,. Lewis M.D, Karloukovski V., Maher B.A., Peglar S.M., Preece R.C., Whittaker J.E., Stringer C.B. ,2005. The earliest record of human activity in northern Europe, Nature 438(15), 1008-1012.

Parfitt, S.A., Ashton, N., Lewis, S.G., Abel, R.L., Coope, G.R., Field, M.H., Gale, R., Hoare, P.G., Larkin. N.R., Lewis, M.D., Karloukovski, V., Maher, B.A., Peglar, S.M., Preece, R.C., Whittaker, J.E., Stringer, C.B., 2010. Early Pleistocene human occupation at the edge of the boreal zone in northwest Europe. Nature 466, 229233.

Pargeter, J., Duke, H., 2015. "Evolutionary perspectives on bipolar technology ": Introduction to the exploring variability in bipolar technolology special edition of Lithic Technology, Lithic Technology.

Pei, W. C. 1936. Le Rôle des phénomènes naturels dans l'éclatement et le façonnement des roches dures utilisées par I'Homme préhistorique, Revue de Géographie physique et de Géologie dynamique, IX, 75 p.

Peña P. de la , 2015. A qualitative guide to recognize bipolar knapping for flint and quartz, Lithic Technology.

Peña Alonzo P. de la, Toscano, L.G.V.? 2013. Bipolar knapping in gravettian occupation at el Palomar rockshelter (Yesre, Sotheastern Spain). Journal of Anthropological Research, 69(1), 33-64

Peretto, C., 2006. The first peopling of Southern Europe: the Italian case. Palevol 5, 283-290.

Peretto, C., Amore, O., Antoniazzi, A., Bahain, J.J., Cattani, L., Cavallini, E., Esposito, P., Falguères, C., Hedley, C., Laurent, I., Le Breton, V., Longo, L., Milliken, S., Monegatti, P., Ollé, A., Pugliese, A., Renault-Miskosky, J., Sozzi, M., Ungaro, S., Vannucci, S., Vergés, J.M., Wagner, J.J., Yokoyama, Y., 1998. L'industrie lithique de Cà Belvdere i Monte Poggiolo: stratigraphie, matière première, typologie, remontage et traces d'utilisation. Anthropologie 102, 343-466.

Piperno, M. (Ed.), 1999. Notarchirico. Un sito del Pleistocene medio iniziale nel bacino di Venosa. Edizioni Osanna.

Raynal, J-P., Magoga, L., Bindon, P. 1995. Tephofracts and the Early Human Occupation at the French Massif Central. In: W. Roebroeks, T. Van Kolfschoten (eds.), The Earliest occupation of Europe, University of Leiden, pp. 129-146.

Raynal, J-P., Magoga, L., Bulle, T., Guadelli, J-L., Maigne, S. 1996. Quelle préhistoire ancienne en Basse Auvergne et Velay ? In: A. Tuffreau (ed.), L'Acheuléen dans l'Ouest de l'Europe. Actes du colloque de SaintRiquier, 1989, CERP, 4, pp. 115-127.

Raynal, J-P., Magoga, L. 2000. Quand la nature mystifie le préhistorien. Géofacts et téphrofacts dans le Massif Central. Nouvelles archéologiques. Du terrain au laboratoire .... Revue d'Auvergne, 554-555(1-2).

Rodríguez-Gómez, G., Mateos, A., Marteos-González, J.A., Blasco, R., Rosell, J., Rodríguez J., 2014. Discontinuity of Human Presence at Atapuerca during the Early Middle Pleistocene: A Matter of Ecological Competition?. PlosOne vol. 9 (7), e101938.

Rodríguez-Álvarez, X.P., 2016. The use of quartz during the Lower Palaeolithic in northeastern Iberia. Quaternary International 424, 69-83. 
Rolin, P., 1981. Géologie et structure du Plateau d'Aigurande dans la région d'Eguzon (NW du Massif central français). Thèse de 3e cycle, Université Paris-sud, Orsay, 229 p.

Rolin, P., Quénardel, J.M., 1980. Nouvelle interprétation du renversement de la série crystallophyllienne du plateau d'Aigurande (nord-ouest du Massif central, France). Compte Rendu Académie des Sciences, Paris, II, 290, 17-20.

Rolin, P., Quénardel, J.M., 1982. Modèle de mise en place syntectonique d'un massif de leucogranite hercynien (Crozant-NW du Massif central français). Compte Rendu Académie des Sciences, Paris, (II), 294, 463-466.

Rolin, P., Dutout, J.L., Quénardel, J.M., 1982. Datation Rb/Sr des leucogranites de Crozant et d'Orsennes. Conséquences sur l'âge de la dernière phase tectonique tangentielle sur le plateau d'Aigurande (NW du Massif central français). C-R Académie des Sciences, Paris, (II), 294, 799-802.

Rolin, P., Quénardel, J.M., Prost, A., 1980. Tectonique tangentielle et mise en place syntectonique des leucogranites au NW du Massif central (France). $26^{\mathrm{e}}$ congrès géologique international, Paris, résumés, 1 (5), 383.

Rosas, A., Perez-Gonzalez, A., Carbonell, E., Van der Made, J., Sanchez, A., Laplana, C., Cuenca-Bescos, G., Parés, J.M., Huguet, R., 2001. Le gisement pleistocene de la Sima del Elefante, (Sierra de Atapuerca, Espagne). L'Anthropologie. 105, 301-312.

Sánchez-Yustos, P., Diez-Martín, F., Domínguez-Rodrigo, M., Fraile, C., Duque, J., Uribelarrea, D., Mabulla, A., Baquedano, E., 2016. Techno-economic human behavior in a context of recurrent megafaunal exploitation at $1.3 \mathrm{Ma}$. Evidence from BK4b (Upper Bed II, Olduvai Gorge, Tanzania). Journal of Archaeological Science: Reports 9, 386-404.

Sangata, C. 2016. Operating systems in units B and E of the Notarchirico (Basilicata, Italy) ancient Acheulean open-air site and the role of raw marerials. Quaternary International, 411, 284-300

Semaw, S., Rogers, M.J., Harris, C., Feibel, S., Bernor, S., Fessaha, N., Mowbray, R., 1997. 2,5 million-yearsold stone tools from Gona, Ethiopia, Nature 385, 333-336.

Shchenlinsky, V.E., Dodonov, A.E., Baigusheva, V.S., Kulakov, S.A., Simakova, A.N., Tesakov, A.S., Titov, V.V., 2008. Early Paleolithic sites on the Taman Peninsula (Southern Azov Sea Region), International Conference, Abstracts, Krasnodar-Temriuk, Russie, Académie des Sciences de Russie, 109-114.

Shchenlinsky, V.E., Dodonov, A.E., Baigusheva, V.S., Kulakov, S.A., Simakova, A.N., Tesakov, A.S., Titov, V.V., 2010. Early Palaeolithic sites on the Taman Peninsula (Southern Azov Sea region, Russia): Bogatyri/Sinyaya Balka and Rodniki. Quat. Int. 223-224,28-35.

Shott, M. J., 1989. Bipolar industries: ethnographic evidence and archaeological implications. North American Archaeologist, 10 (1), 1-24.

Shott, M. J., 1999. On bipolar reduction and splintered pieces. North American Archaeologist 20, 217-238.

Stout, D., Semaw, S., 2005. Knapping skill of the earliest toolmakers: insights from the study of modern human novices. In: Toth, N., Schick, K. (Eds.), The Oldowan: Case Studies into the Earliest Stone Age. Stone Age Institute Press, Gosport, 307e332.

Tallavaara, M., Manninen, M., Hertell, E., Rankama, T., 2010. How flakes shatter: a critical evaluation of quartz fracture analysis. J. Archaeol. Sci. 37, 2442-2448. 
Tavoso, A., 1986. Le Paléolithique inférieur et moyen du Haut-Languedoc. Gisements des terrasses alluviales du Tarn, du Dadou, de l'Agout, du Sor et du Fresquel. Laboratoire de Paléontologie et de Préhistoire, Marseille. Université de Provence.

Texier, J.-P., 1995. The Oldowan assemblage from NY18 site at Nyabusosi (Toro-Uganda) $=$ L'ensemble lithique oldowayen du site NY 18 à Nyabusosi (Toro-Ouganda). C.R. Académie des Sciences, 320 (7), 647653.

Torre, I. de la ., Mora, R., 2005. Unmodified lithic material at Olduvai. Bed I: manuports or ecofacts? J Archaeol Sci. 32,273-285.

Torre, I. de la, Mora R. Martinez-Moreno, J., 2008. The early Acheulean in Peninj (Lake Natron, Tanzania). Journa of Anthropolpgical Archaeology, 27(2), 244-264.

Torre, I. de la, Mora, R., 2010. A technological analysis of non-flaked Stone tolos in Olduvai Beds I \& II. Stressing the relevance of percussion activities in the African Lower Pleistocene. Paleo, revue d'Archéologie préhistorique, (special) 13-34.

Torre, I. de la I, Hirata, S. 2015. Percussive technology in human evolution: an introduction to a comparative approach in fossil and living primates. Phil. Trans. R. Soc. B, 370(1682), 20140346.

Toro-Moyano I., Lumley de, H., Barsky, D., Celiberti, V., Cauche, D., Moncel, M-H., Fajardo, B., Toro, M., 2003. Las industrias liticas de Barranco Leon y Fuente Nueva 3 de Orce. Estudio tecnico y tipologico. Las cadenas operativas. Analisis traceologico. Resultados preliminares, In Toro I., Agusti J., Martinez-Navarro B. eds., El Pleistoceno inferior de Barranco Leon y Fuente Nueva 3, Orce (Granada), Memoria scientifica comparas 1999-2002, Ed. Junta de Andalucia, Consejeria de Cultura, Arqueologica Monografias (Isidro Toro, Jordi Agusti \& Bienvenido Martinez-Navarro coord.), 183-206.

Toro-Moyano, I., de Lumley, H., Fajardo, B., Barsky, D., Cauche, D., Celiberti, V., Grégoire, S., MartinezNavarro, B., Patrocinio Espigares, M., Ros-Montoya, S., 2009. L'industrie lithique des gisements du Pléistocène inférieur de Barranco León et Fuente Nueva 3 à Orce, Grenade, Espagne. L'Anthropologie 113, 111-124.

Vallverdu, J., Saladié, P., S., Rosas, A., Huguet R., Caceres, I., Mosquera, M., Garcia-Tabernero, A., Estalrrich, A., Lozano-Fernandez, I., Pineda-Alcala, A., Carrancho, A., Villalaın, J-J., Bourle, D., Braucher, R., Lebatard, A., Vilalta Montserrat Esteban-Nadal, J., Lluc Benna, M., Bastir, M., Lopez-Polın, L., Olle, A., Verge, J-M., RosMontoya, S., Martınez-Navarro, B., Garcıa, A., Martinell, J., Exposito, I., Burjachs, F., Agustı, J., Carbonell, E., 2014. Age and Date for Early Arrival of the Acheulian in Europe (Barranc de la Boella, la Canonja, Spain). PlosOne 9 (Issue 7), e103634.Van Vliet-Lannoé, B., 1987. Le rôle de la glace de ségrégation dans les formations superficielles de l'Europe de l'Ouest. Processus et héritage. Thèse de doctorat d'Etat, Université de Paris I- Sorbonne. Editec Caen 854 p.

Vergès, J.M., Ollé, A., 2011. Technical MicroWear and Residues in Indentifying Bipolar Knapping on an Anvil : Experimental Data. Journal of Archaeological Science, 38(5), 1016-1025.

Voinchet, P., 2002. Datation par résonance paramégnétique électronique (RPE) de quatrz blanchis extraits de sédiments fluviatiles pléistocènes: contribution méthodologique et application aux systèmes de la Creuse, du Loir et de l'Yonne. Thèse du Muséum national d'Histoire naturelle, Paris, 350p.

Voinchet, P., Despriée, J., Gageonnet, R., Falguères, C., Bahain, J.-J., Tissoux, H., Dépont, J., Dolo, J.-M., 2007. Datation par ESR de quartz sédimentaire : mise en évidence de la tectonique au Quaternaire et de son influence dans la géométrie des nappes alluviales du bassin de la Loire moyenne en région Centre. Quaternaire 18 (4), 335-347. 
Voinchet, P., Despriée, J., Tissoux, H., Falguères, C., Bahain, J.-J., Gageonnet, R., Dépont, J., Dolo, J.-M., 2010. ESR chronology of alluvial deposits and first human settlements of the Middle Loire Basin (Region Centre, France). Quaternary Geochronology 5 (2-3), 381-384.

Wisniewski, A., Badura, J., Salamon, T. and Lewandowski, J.z., 2014. The alleged Early Palaeolithic artefacts are in reality geofacts: a revision of the site of Konczyce Wielkie 4 in the Moravian Gate, South Poland Journal of Archaeological Science 52 (0), 189-203.

Würges, K., 1984. Altpaläolithische Funde aus der Tongrube Kärlich (Schicht H unten), Kreis MayenKoblenz/Neuwieder Becken, Arch. Korrbl. 14, 17-22.

Zaidner, 2013. Adaptive Flexibility of Oldowan Hominins: Secondary Use of Flakes at Bizat Ruhama, Israel. Plos One 8 (6), e66851. 


\section{Figure captions}

Figure 1. Location of the Pont-de-Lavaud site, commune of Eguzon-Chantôme, department of Indre, Centre-Val de Loire region, France (Latitude: $46^{\circ} 26^{\prime} 32^{\prime \prime}$ North; longitude: $1^{\circ} 58^{\prime} 25^{\prime \prime}$ East) and location of the main sites occupied during the Early Pleistocene.

Figure 2. 1. Location of the Pont-de-Lavaud site: A. on the Aigurande plateau; B. on the Fressignes interfluve. 1. Paris Basin sediments; 2. Migmatitic unit; 3. Dun-Gargilesse gneiss unit; 4. Eguzon amygdaloidal gneiss unit; 5. Fougères-Culan micaschist unit; 6, 7. Leucogranite and granite; Boussac metamorphic and magmatic formations; 9. Marche granite; 10. Guéret granite; 11. Chéniers granite (after Despriée and Gageonnet, 2003, modified). The arrows indicate the direction of the transportation of different types of quartz during Tertiary and Quaternary periods.

Figure 3. Reconstruction of the successive stages of the Pont-de-Lavaud sequence deposition

Figure 4. A. The stepped fossil fluvial system of the Creuse River (after Voinchet et al., 2010). For each alluvial sheet the weigted ESR age is indicated. The Pont-de-Lavaud site is associated with sheet I.

Figure 5. Spatial analysis of the studied retouched quartz blanks shown on the diagram, they are mainly associated with the two pavements, but their spatial distribution is also consistent with the general distribution of quartz tools. More than $60 \%$ of the retouched artefacts are concentrated in the two pavements and do not show any preferential orientation.

Figure 6. Evolution of pebble/cobble/ boulder sizes from the bottom to the surface. Pebbles represent most of the material I $\mathrm{n}$ the archaeological surface (pebble layer), cobbles are characteristic of the diamicton and boulders are located on the micashsit bedrock at the bottom of the diamicton.

Figure 7. Classes of pebbles and debris from the Pont-de-Lavaud site. (1) Well-rounded pebble or cobble; (2) Pebblewith natural break; (3) Pebble with impacts at the top; (4) Pebble with peels; $(5,6)$ Pebble broken into twoparts with plane, salient or re-entrant angles; (7) Pebble broken into three fragments with right or acuteangles; (8) Pebble broken into three fragments with thin triangular debris. Impacts are visible.

Figure 8. Tests consisting of breaking very hard quartz pebbles or cobbles. (1) Pieces are placed flat on the anvil surface and struck with an amygdaloid quartz cobble used as a hammer stone. (2) After one blow, the pebble is broken into two parts. (3) After two blows, remetamorphized quartz is broken into fourfragments. (4) During the shock, some fragments remain on the anvil surface, but others are dispersed over one or two meters. (Experimentation by J. Despriee and P. Alilaire, photos P.Touchard). 
Figure 9. Results of the breaking experiment. $(1,2)$ Blanks gathered on the diamicton; $(3,4)$ Hammer stones with scars visible on the tip; (5 to 8 ) Fragmentation of quartz cobbles on the anvil surface with fragments smaller than half of the original surface; 5 . Cobbles truncated at one or two ends, with right-angled fracture and skullcap-shaped fragments; 6, 7. Cobbles broken in one blow with two triangular debris or two segment-shaped pieces; 8 . Cobble broken by numerous blows with segment-shaped fragments and sharpedged debris.

Figure 10. Photographs of different types of pieces with presumed anthropogenic features. (1) Block of vein quartz with numerous impact marks on the upper surface and removal scars on the orthogonal edges; $(2,3)$ Amygdaloid quartz cobbles with crushing scars on one end or with splintered tip (Types 3 and 4); (4, 5)Fragments of quartz cobbles with orthogonal fresh surfaces, impacts, circular apex of the cone, cones andelevations. Some crushing is visible on the opposite surfaces (Types 5 and 7a); (6) Amygdaloid quartz cobblewith two fresh orthogonal surfaces and acute tip. Two impact marks are visible on the obverse side, as wellas crushing on the reverse face (Type 6) $\left(n^{\circ} 7,8,9\right)$. Fragments of quartz cobbles with fresh angular surfaces,impacts visible on the apex of the angle and crushing on the opposite trihedral apex (Types $7 \mathrm{~b}, 7 \mathrm{c}$ and 7d) (Photos G. Courcimault).

Figure 11. Percussion techniques and related blanks. Direct percussion is mainly associated with the production of blanks intended for "retouch". Bipolar percussion is primarily associated with the initiation of block breakage or very short reduction sequences. Cores and flakes from direct percussion core technology.

Figure 12. Examples of quartz cores (or chopper-cores) with cortical platforms $(1,3)$ and flat pebbles broken by the bipolar technique (2) or the platform of a previous removal (4). The arrow indicates the impact point (photos M-H. Moncel and M. Arzarello).

Figure 13. Examples of quartz cores (or chopper-cores) on one or two orthogonal surfaces perpendicular to the cortical surfaces (drawings A. Theodoropoulou).

Figure 14. Quartz core-pebble tools $\left(n^{\circ} 1,2,3\right)$, denticulates on a fragment of quartz $\left(n^{\circ} 5\right)$ or a flake $\left(n^{\circ} 4,7\right)$, and core-tool with centripetal scars? $\left(n^{\circ} 6\right)$ (drawings J. Despriée)

Figure 15. A: Estimated volume of the cores (mm3) made by direct percussion by hard hammer and by bipolar percussion on anvil. The reduction phase is longer when direct hard hammer percussion is used, as is confirmed by smaller core morphologies.B. :Boxplot of the maximal dimension (in $\mathrm{mm}$ ) of all the whole flakes (quartile method rounding; Whisker type: standard error); for unipolar/multipolar core technology and centripetal core technology, flakes with and without cortex are included. The graphs show that the 
dimensions are similar regardless of core technology. The non-cortical flakes have the same average dimension with lower variability, generally smaller than the cortical flakes. This is related to the morphology of the raw material.

Figure 16. Partial bifacial piece on quartz. Both sides of the pebble were shaped by alternate striking (drawings A. Theodoropoulou).

Figure 17. Examples of cortical quartz flakes with some removals $(1,2,3)$. Denticulate on a cortical flake (4) (drawing J. Despriée)

Figure 18. Maximum dimensions (in $\mathrm{mm}$ ) of the retouched (red columns) and non-retouched (blue columns) whole flakes. No evident selection based on dimensions is observed for the retouched pieces.

Figure 19. Reduction processes on quartz pebbles at Pont-de-Lavaud according to pebble geometry and the type of percussion A. Bipolar technique with pebbles broken on the longest face; B. Bipolar technique with pebbles broken on the tip; C. Pebbles with one removal; D. Pointed or linear pebble-tools with two removals ; E. Pointed pebble-tools including the proto-biface; F. Cores on oval pebbles with unipolar removals on one flaking surface with cortical platform; G. and L. Cores on pebbles with unipolar removals and two orthogonal flaking surfaces; H. and K. Cores on rectangular pebbles with unipolar removals on one flaking surface located on the side of the pebble with a cortical platform; I. Rectangular pebbles with one removal on the edge; J. Cores on rectangular pebbles with unipolar removals on one flaking surface located on the largest face of the pebble with a cortical platform.

\section{Supplementary data}

Suppl. 1. View of the accumulation surfaces (Pavement) Pont-de-Lavaud 1 and Pont-de-Lavaud 2, corresponding to concentrations of blocks with linear borders and peripheral holes. 1: Spatial distribution of the vein quartz manuports (blocks $\geq 10 \mathrm{~cm}$ long). 2 and 3 : Vertical sections show the links between paving stones (2) and accumulation of lithic artefacts (3) with wall-effect (after Despriée et al, 2010, 1011).

Supp. 2A: Stone accumulation of Pont-de-Lavaud 1. The view from the south also shows the large isolated peripheral blocks on the micaschist bedrock. Suppl. 2 B: Holes surrounded with quartz cobbles on the northern edge (photos J. Despriée).

Supp. 3. Photographs of experimental artefacts. (1) Block of vein quartz used as an anvil with impacts on the obverse end and lateral crushing; $(2,3)$. Amygdaloid cobbles used as hammer stones, with use scars; $(4,5)$ Cobbles broken by one blow (types 5 and fragments 7 a, $7 c$ ): impact marks, cone and crushing on 
reverse face; $(6,7)$ Cobbles broken by two blows (types 6 and fragments 7c, 7d); impact marks, cones and crushing on the opposite surface; (8). Cobble broken by three blows (type 6 with debris type 8) (Experimentation by J. Despriée and P. Alilaire, photos G. Courcimault).

Suppl. 4. Partial bifacial piece on quartz. Both sides of the pebble were shaped by alternate striking (photos M-H. Moncel). 


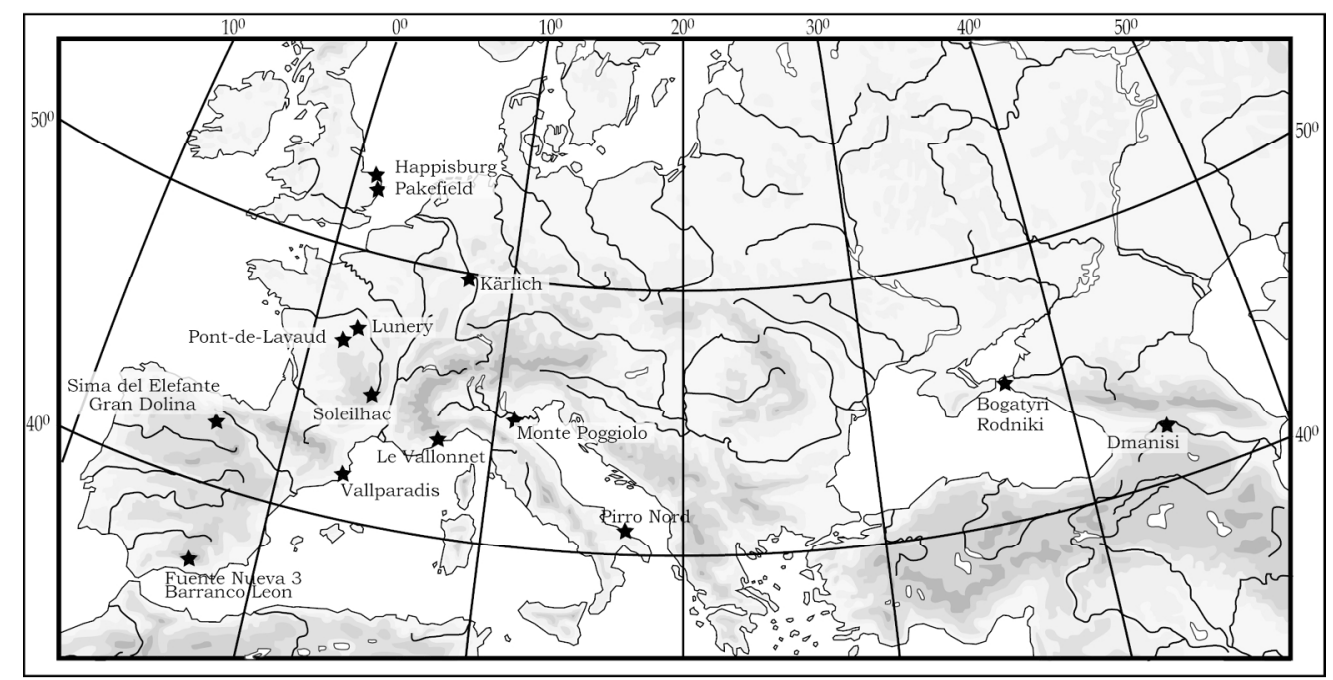

Figure 1. Location of the Pont-de-Lavaud site, commune of Eguzon-Chantôme, department of Indre, Centre-Val de Loire region, France (Latitude: 46 26'32" North; longitude: $1^{\circ} 58^{\prime} 25^{\prime \prime}$ East) and location of the main sites occupied during the Early Pleistocene.

$170 \times 87 \mathrm{~mm}(300 \times 300 \mathrm{DPI})$ 
Figure 2. 1. Location of the Pont-de-Lavaud site: A. on the Aigurande plateau; B. on the Fressignes interfluve. 1. Paris Basin sediments; 2. Migmatitic unit; 3. Dun-Gargilesse gneiss unit; 4. Eguzon amygdaloidal gneiss unit; 5. Fougères-Culan micaschist unit; 6, 7. Leucogranite and granite; Boussac metamorphic and magmatic formations; 9. Marche granite; 10. Guéret granite; 11. Chéniers granite (after Despriée and Gageonnet, 2003, modified). The arrows indicate the direction of the transportation of different types of quartz during Tertiary and Quaternary periods.

$194 \times 171 \mathrm{~mm}(300 \times 300 \mathrm{DPI})$ 


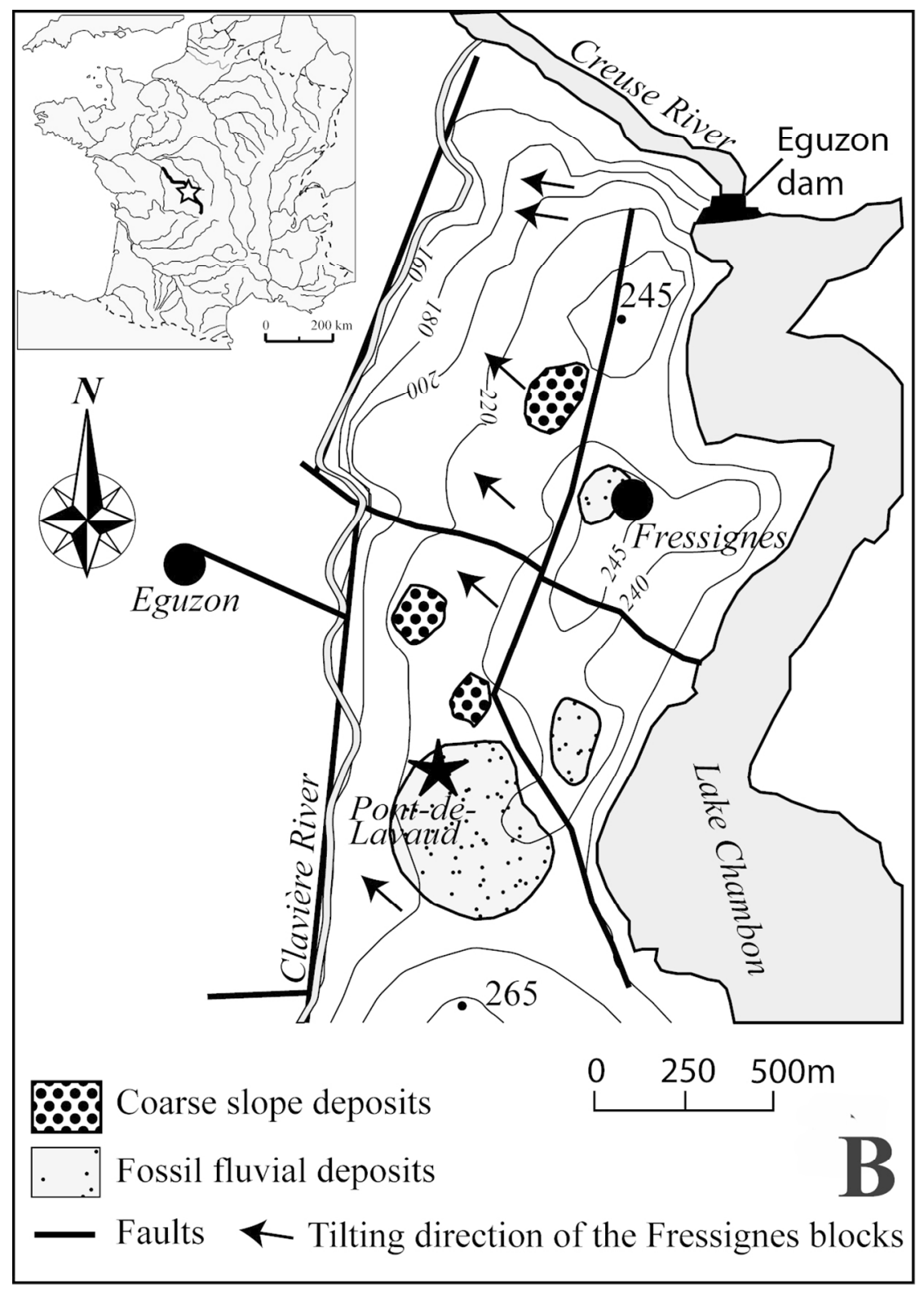

Figure 2. 1. Location of the Pont-de-Lavaud site: A. on the Aigurande plateau; B. on the Fressignes interfluve. 1. Paris Basin sediments; 2. Migmatitic unit; 3. Dun-Gargilesse gneiss unit; 4. Eguzon amygdaloidal gneiss unit; 5. Fougères-Culan micaschist unit; 6, 7. Leucogranite and granite; Boussac metamorphic and magmatic formations; 9. Marche granite; 10. Guéret granite; 11. Chéniers granite (after Despriée and Gageonnet, 2003, modified). The arrows indicate the direction of the transportation of different types of quartz during Tertiary and Quaternary periods.

$104 \times 147 \mathrm{~mm}(300 \times 300 \mathrm{DPI})$ 


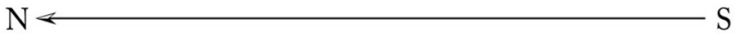

A : Early Glacial - Valley incutting and slope denudation

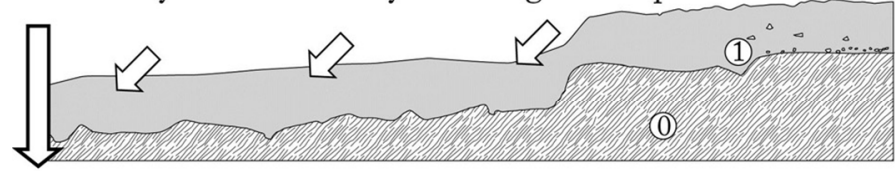

B : Early Glacial - Diamicton deposition

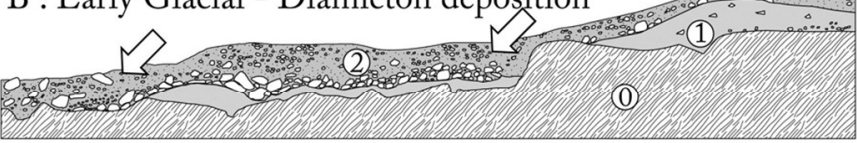

$\mathrm{C}$ : Pleniglacial - Cryoturbation
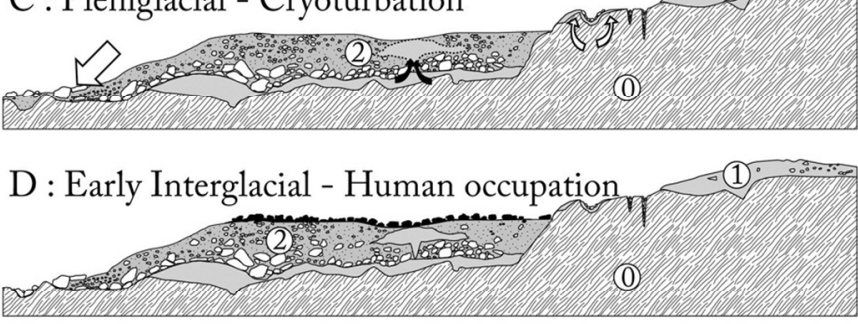

E : Interglacial - Fluvial sand deposition

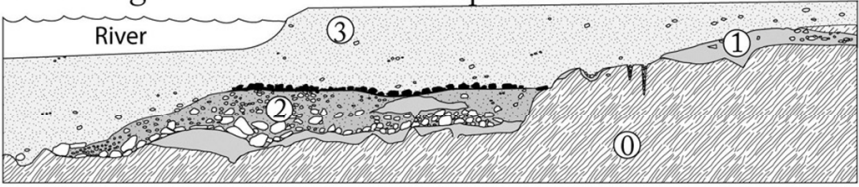

$\mathrm{F}:$ Recent times - Tilting of the block
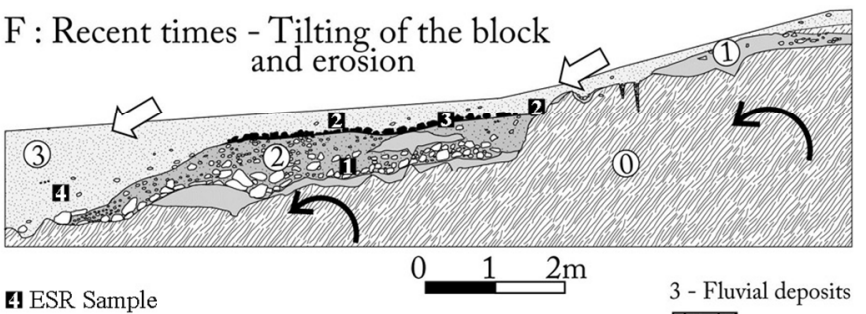

4 ESR Sample

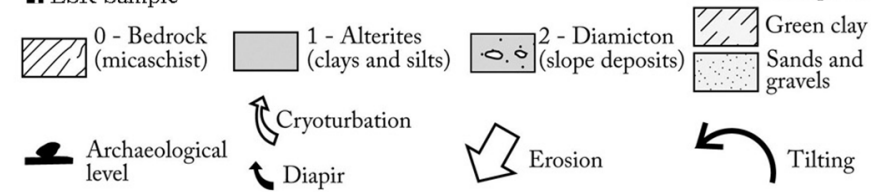

Figure 3. Reconstruction of the successive stages of the Pont-de-Lavaud sequence deposition

$$
80 \times 141 \mathrm{~mm}(300 \times 300 \text { DPI })
$$




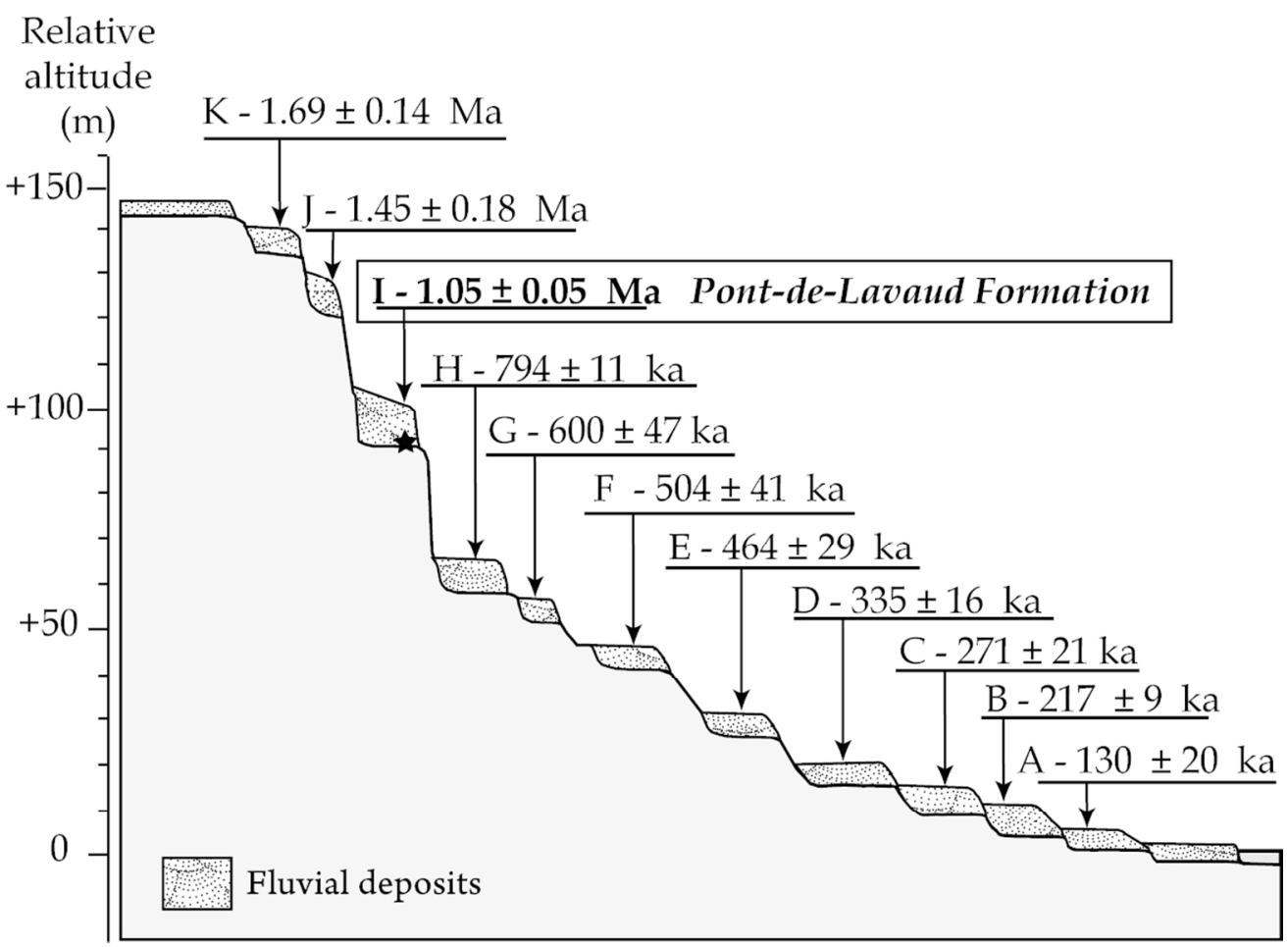

Figure 4. A. The stepped fossil fluvial system of the Creuse River (after Voinchet et al., 2010). For each alluvial sheet the weigted ESR age is indicated. The Pont-de-Lavaud site is associated with sheet I.

$105 \times 76 \mathrm{~mm}(300 \times 300$ DPI $)$ 


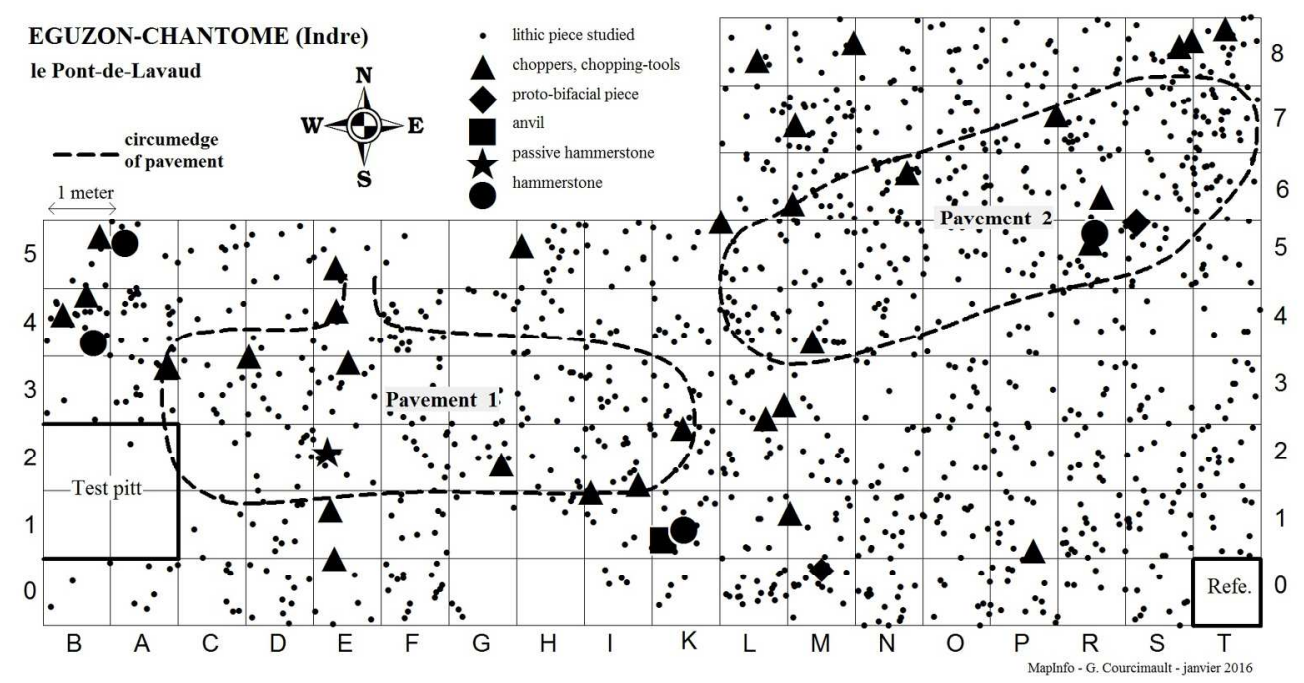

Figure 5. Spatial analysis of the studied retouched quartz blanks (red pentagons). As shown on the diagram, they are mainly associated with the two pavements, but their spatial distribution is also consistent with the general distribution of quartz tools. More than $60 \%$ of the retouched artefacts are concentrated in the two pavements and do not show any preferential orientation.

$$
167 \times 91 \mathrm{~mm}(300 \times 300 \mathrm{DPI})
$$


Figure 6. Evolution of pebble/cobble/ boulder sizes from the bottom to the surface. Pebbles represent most of the material I $n$ the archaeological surface (pebble layer), cobbles are characteristic of the diamicton and boulders are located on the micashsit bedrock at the bottom of the diamicton.

$247 \times 141 \mathrm{~mm}(96 \times 96 \mathrm{DPI})$ 
Figure 7. Classes of pebbles and debris from the Pont-de-Lavaud site. (1) Well-rounded pebble or cobble; (2) Pebblewith natural break; (3) Pebble with impacts at the top; (4) Pebble with peels; $(5,6)$ Pebble broken into twoparts with plane, salient or re-entrant angles; (7) Pebble broken into three fragments with right or acuteangles; (8) Pebble broken into three fragments with thin triangular debris. Impacts are visible.

$170 \times 38 \mathrm{~mm}(300 \times 300$ DPI $)$ 
Figure 8. Tests consisting of breaking very hard quartz pebbles or cobbles. (1) Pieces are placed flat on the anvil surface and struck with an amygdaloid quartz cobble used as a hammer stone. (2) After one blow, the pebble is broken into two parts. (3) After two blows, remetamorphized quartz is broken into fourfragments. (4) During the shock, some fragments remain on the anvil surface, but others are dispersed over one or two meters. (Experimentation by J. Despriee and P. Alilaire, photos P.Touchard).

$104 \times 101 \mathrm{~mm}(300 \times 300 \mathrm{DPI})$ 
Figure 8. Tests consisting of breaking very hard quartz pebbles or cobbles. (1) Pieces are placed flat on the anvil surface and struck with an amygdaloid quartz cobble used as a hammer stone. (2) After one blow, the pebble is broken into two parts. (3) After two blows, remetamorphized quartz is broken into fourfragments. (4) During the shock, some fragments remain on the anvil surface, but others are dispersed over one or two meters. (Experimentation by J. Despriee and P. Alilaire, photos P.Touchard).

$412 \times 385 \mathrm{~mm}(72 \times 72 \mathrm{DPI})$ 
Figure 8. Tests consisting of breaking very hard quartz pebbles or cobbles. (1) Pieces are placed flat on the anvil surface and struck with an amygdaloid quartz cobble used as a hammer stone. (2) After one blow, the pebble is broken into two parts. (3) After two blows, remetamorphized quartz is broken into fourfragments. (4) During the shock, some fragments remain on the anvil surface, but others are dispersed over one or two meters. (Experimentation by J. Despriee and P. Alilaire, photos P.Touchard).

$118 \times 88 \mathrm{~mm}(300 \times 300 \mathrm{DPI})$ 
Figure 8. Tests consisting of breaking very hard quartz pebbles or cobbles. (1) Pieces are placed flat on the anvil surface and struck with an amygdaloid quartz cobble used as a hammer stone. (2) After one blow, the pebble is broken into two parts. (3) After two blows, remetamorphized quartz is broken into fourfragments. (4) During the shock, some fragments remain on the anvil surface, but others are dispersed over one or two meters. (Experimentation by J. Despriee and P. Alilaire, photos P.Touchard).

$152 \times 101 \mathrm{~mm}(300 \times 300 \mathrm{DPI})$ 


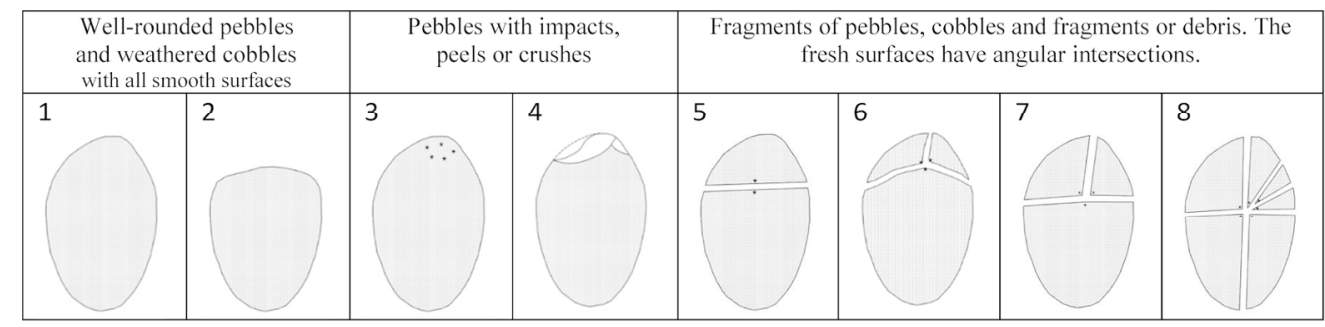

Figure 9. Results of the breaking experiment. $(1,2)$ Blanks gathered on the diamicton; $(3,4)$ Hammer stones with scars visible on the tip; (5 to 8) Fragmentation of quartz cobbles on the anvil surface with fragments smaller than half of the original surface; 5 . Cobbles truncated at one or two ends, with rightangled fracture and skullcap-shaped fragments; 6,7 . Cobbles broken in one blow with two triangular debris or two segment-shaped pieces; 8 . Cobble broken by numerous blows with segment-shaped fragments and sharp-edged debris.

$170 \times 40 \mathrm{~mm}(300 \times 300 \mathrm{DPI})$ 

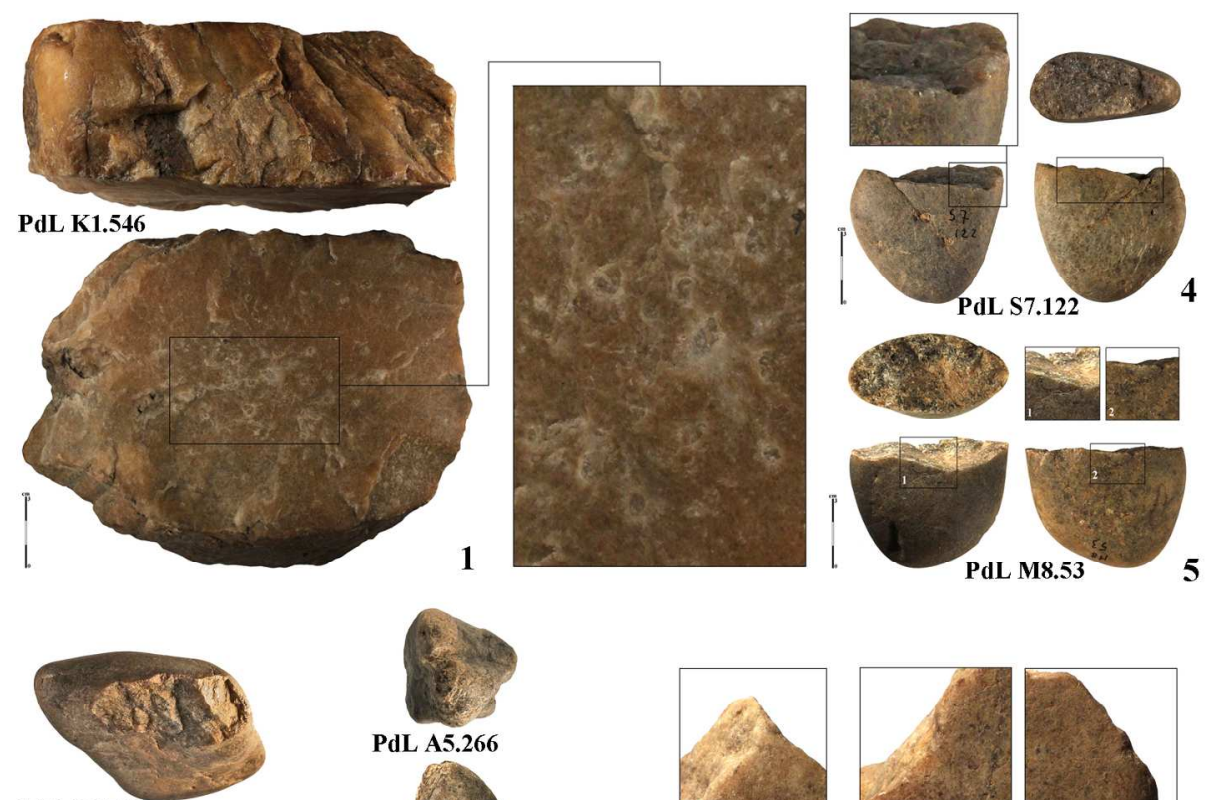

PdL B4.505
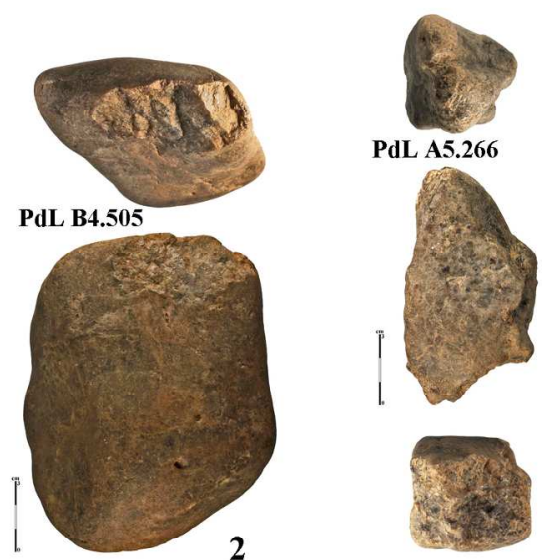

3
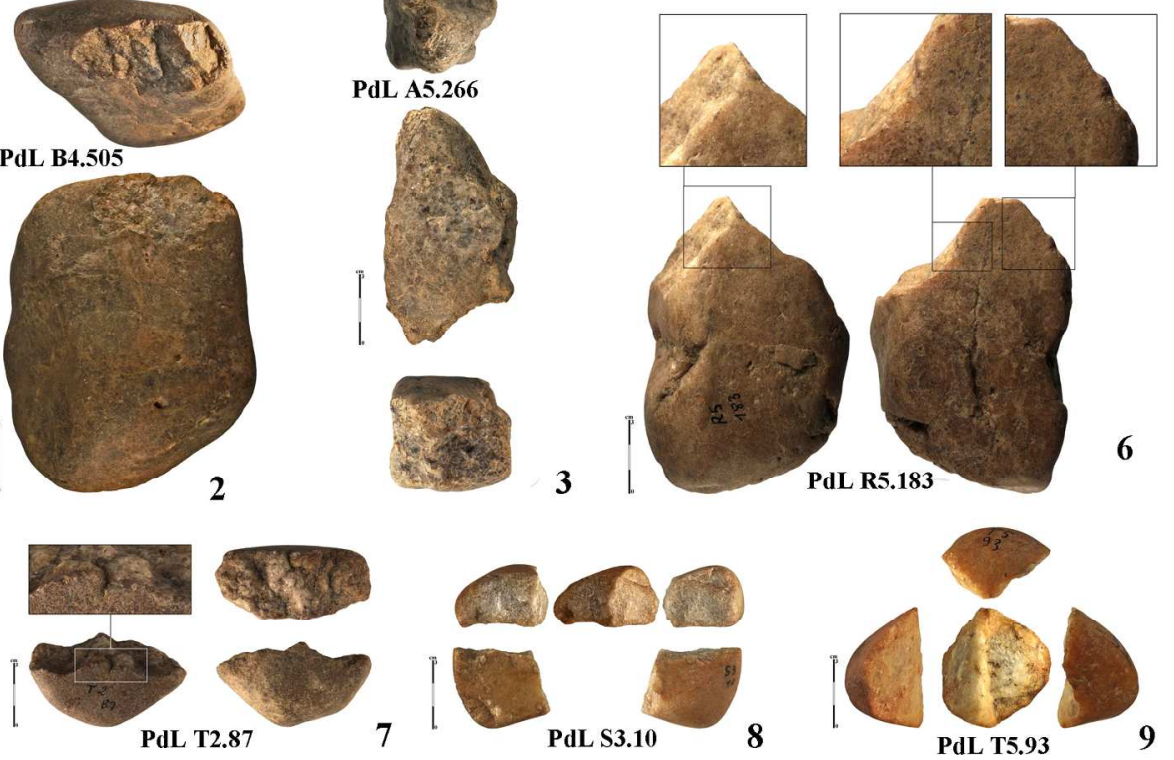

Figure 10. Photographs of different types of pieces with presumed anthropogenic features. (1) Block of vein quartz with numerous impact marks on the upper surface and removal scars on the orthogonal edges; $(2,3)$

Amygdaloid quartz cobbles with crushing scars on one end or with splintered tip (Types 3 and 4); (4,

5)Fragments of quartz cobbles with orthogonal fresh surfaces, impacts, circular apex of the cone, cones andelevations. Some crushing is visible on the opposite surfaces (Types 5 and 7a); (6) Amygdaloid quartz cobblewith two fresh orthogonal surfaces and acute tip. Two impact marks are visible on the obverse side, as wellas crushing on the reverse face (Type 6$)\left(n^{\circ} 7,8,9\right)$. Fragments of quartz cobbles with fresh angular surfaces, impacts visible on the apex of the angle and crushing on the opposite trihedral apex (Types 7b, 7c and 7d) (Photos G. Courcimault).

$170 \times 219 \mathrm{~mm}(300 \times 300$ DPI $)$ 


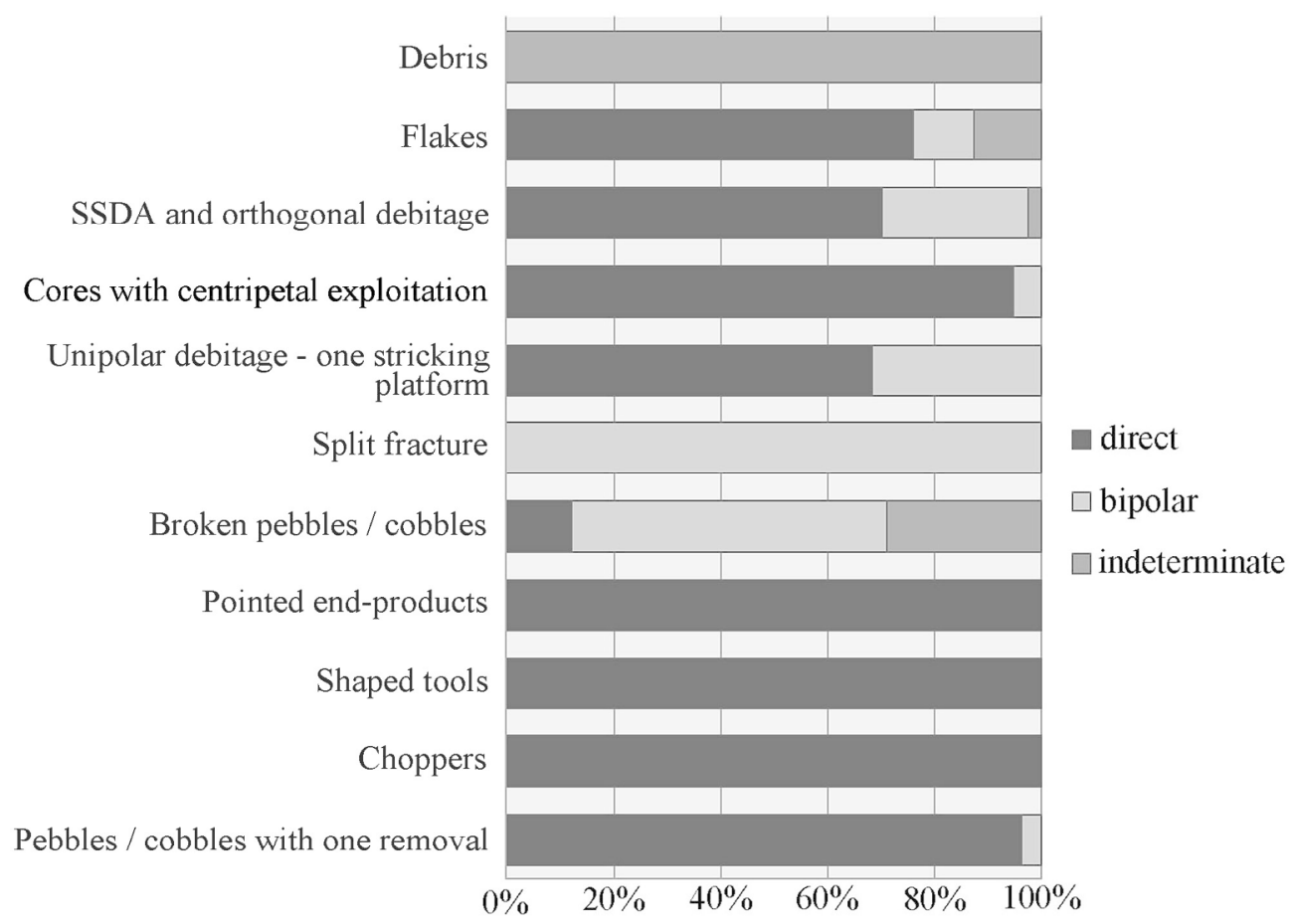

Figure 11. Percussion techniques and related blanks. Direct percussion is mainly associated with the production of blanks intended for "retouch". Bipolar percussion is primarily associated with the initiation of block breakage or very short reduction sequences. Cores and flakes from direct percussion core technology.

$170 \times 130 \mathrm{~mm}(300 \times 300 \mathrm{DPI})$ 

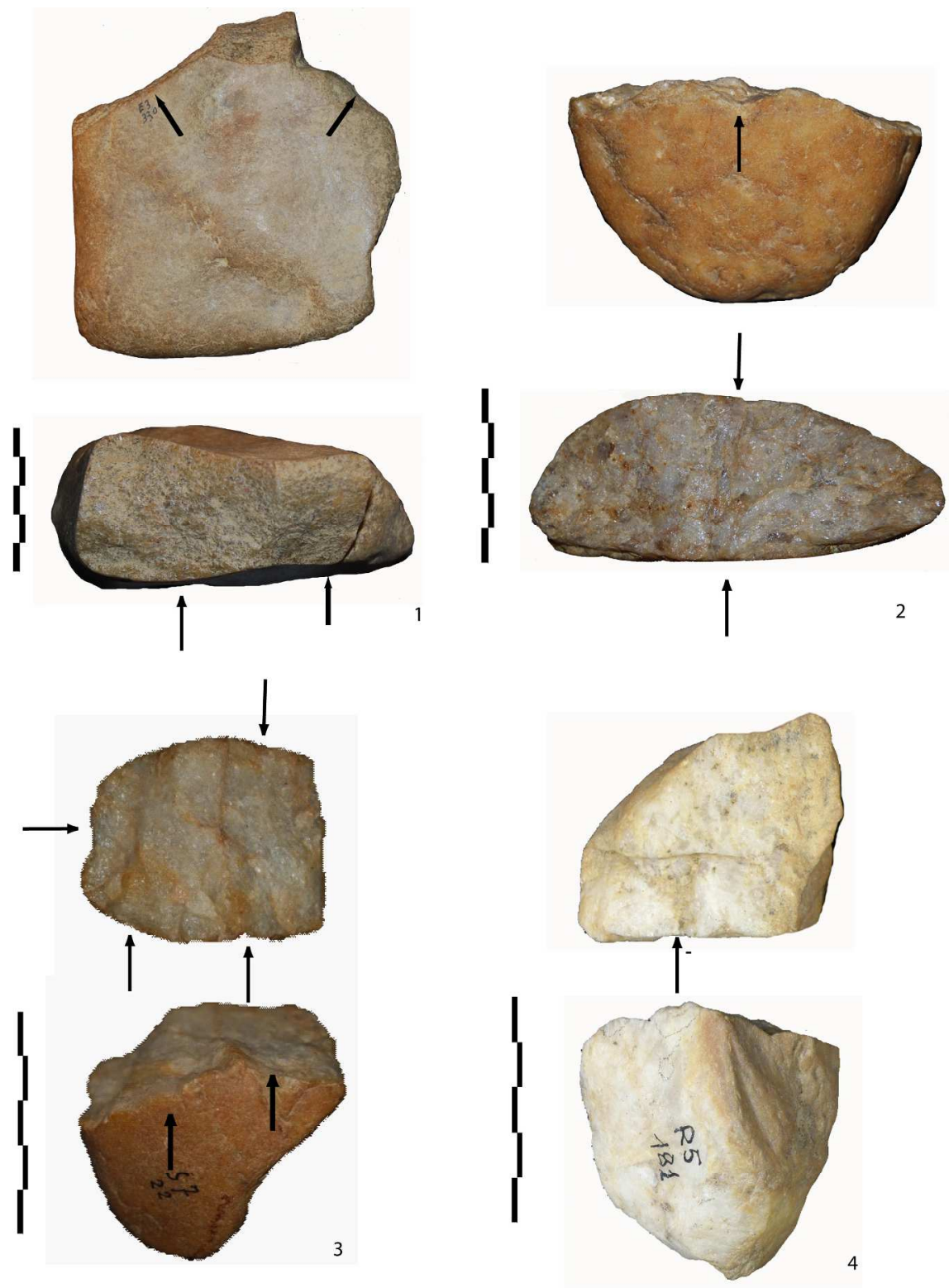

Figure 12. Examples of quartz cores (or chopper-cores) with cortical platforms $(1,3)$ and flat pebbles broken by the bipolar technique (2) or the platform of a previous removal (4). The arrow indicates the impact point (photos M-H. Moncel and M. Arzarello).

\section{$193 \times 265 \mathrm{~mm}(300 \times 300$ DPI $)$}



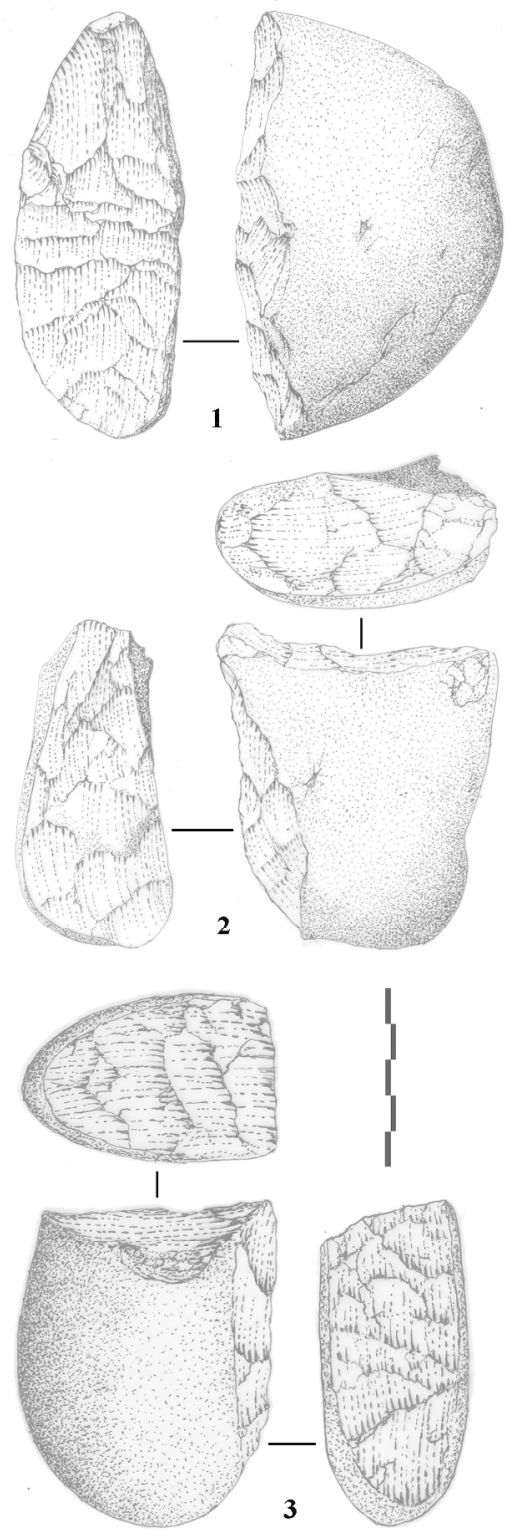

Figure 13. Examples of quartz cores (or chopper-cores) on one or two orthogonal surfaces perpendicular to the cortical surfaces (drawings A. Theodoropoulou).

$75 \times 230 \mathrm{~mm}(300 \times 300 \mathrm{DPI})$ 


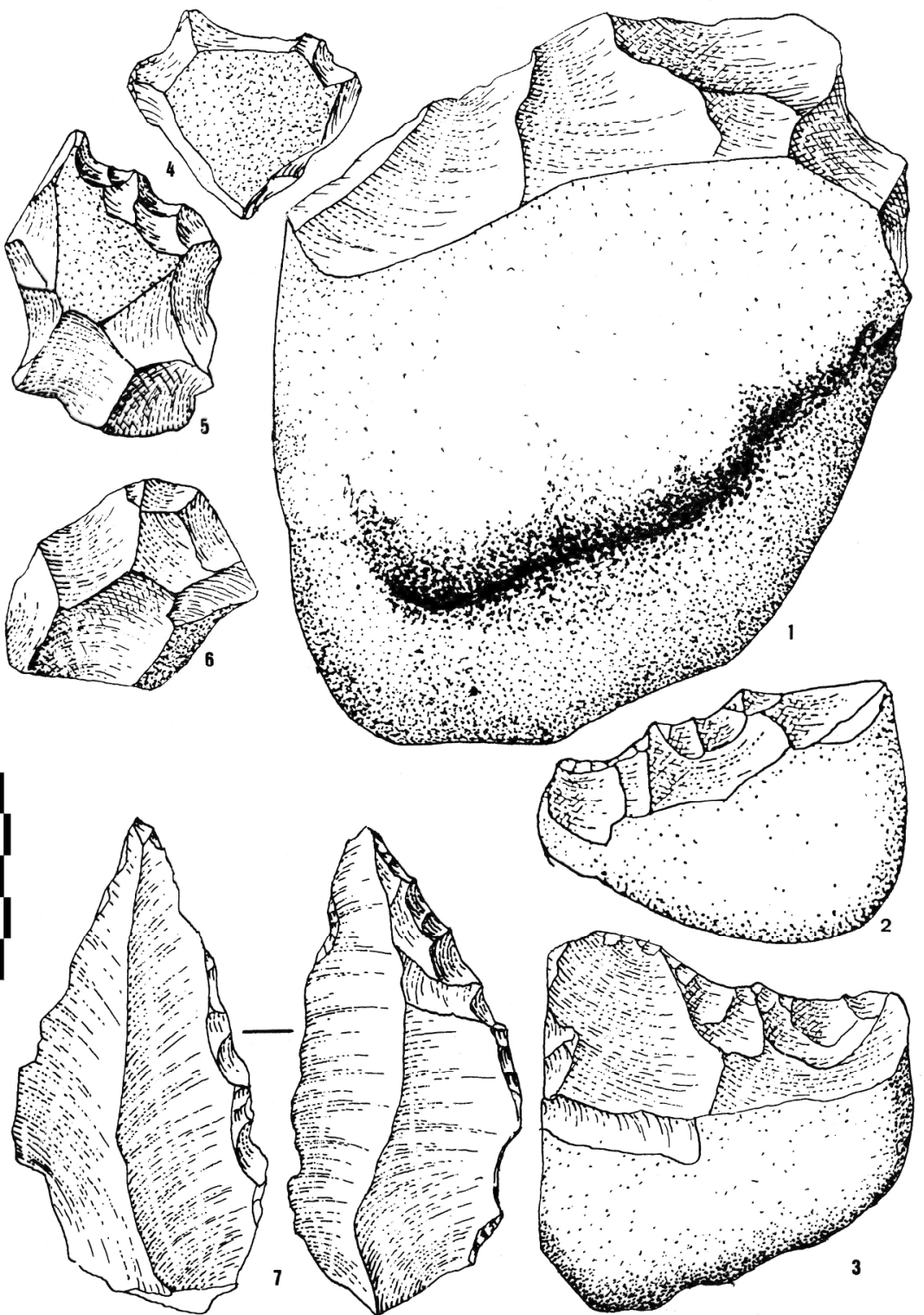

Figure 14. Quartz core-pebble tools $\left(n^{\circ} 1,2,3\right)$, denticulates on a fragment of quartz $\left(n^{\circ} 5\right)$ or a flake $\left(n^{\circ} 4\right.$, 7 ), and core-tool with centripetal scars? $\left(n^{\circ} 6\right)$ (drawings J. Despriée).

$186 \times 258 \mathrm{~mm}(300 \times 300 \mathrm{DPI})$ 
Figure 15. A: Estimated volume of the cores $(\mathrm{mm} 3)$ made by direct percussion by hard hammer and by bipolar percussion on anvil. The reduction phase is longer when direct hard hammer percussion is used, as is confirmed by smaller core morphologies.B. :Boxplot of the maximal dimension (in $\mathrm{mm}$ ) of all the whole flakes (quartile method rounding; Whisker type: standard error); for unipolar/multipolar core technology and centripetal core technology, flakes with and without cortex are included. The graphs show that the dimensions are similar regardless of core technology. The non-cortical flakes have the same average dimension with lower variability, generally smaller than the cortical flakes. This is related to the morphology of the raw material.

\section{$156 \times 249 \mathrm{~mm}(96 \times 96 \mathrm{DPI})$}




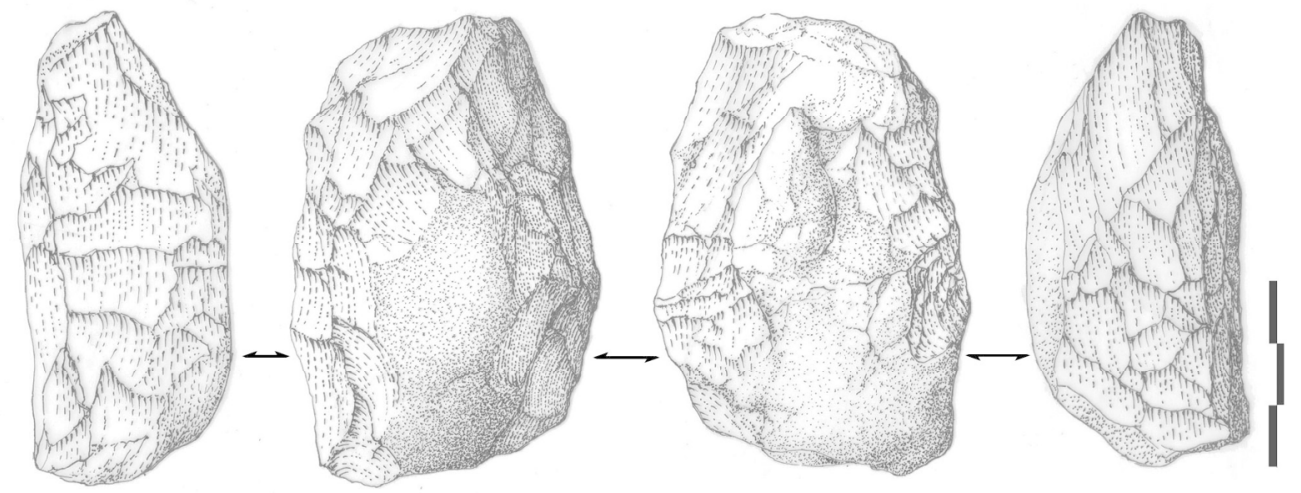

Figure 16. Partial bifacial piece on quartz. Both sides of the pebble were shaped by alternate striking (drawings A. Theodoropoulou). $170 \times 66 \mathrm{~mm}(300 \times 300 \mathrm{DPI})$ 

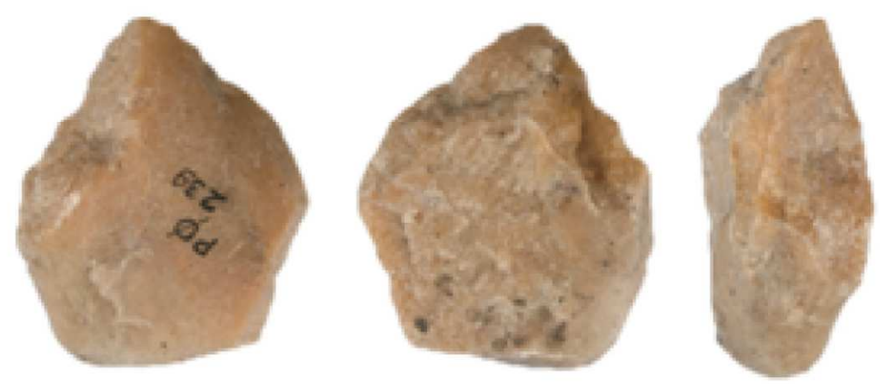

1
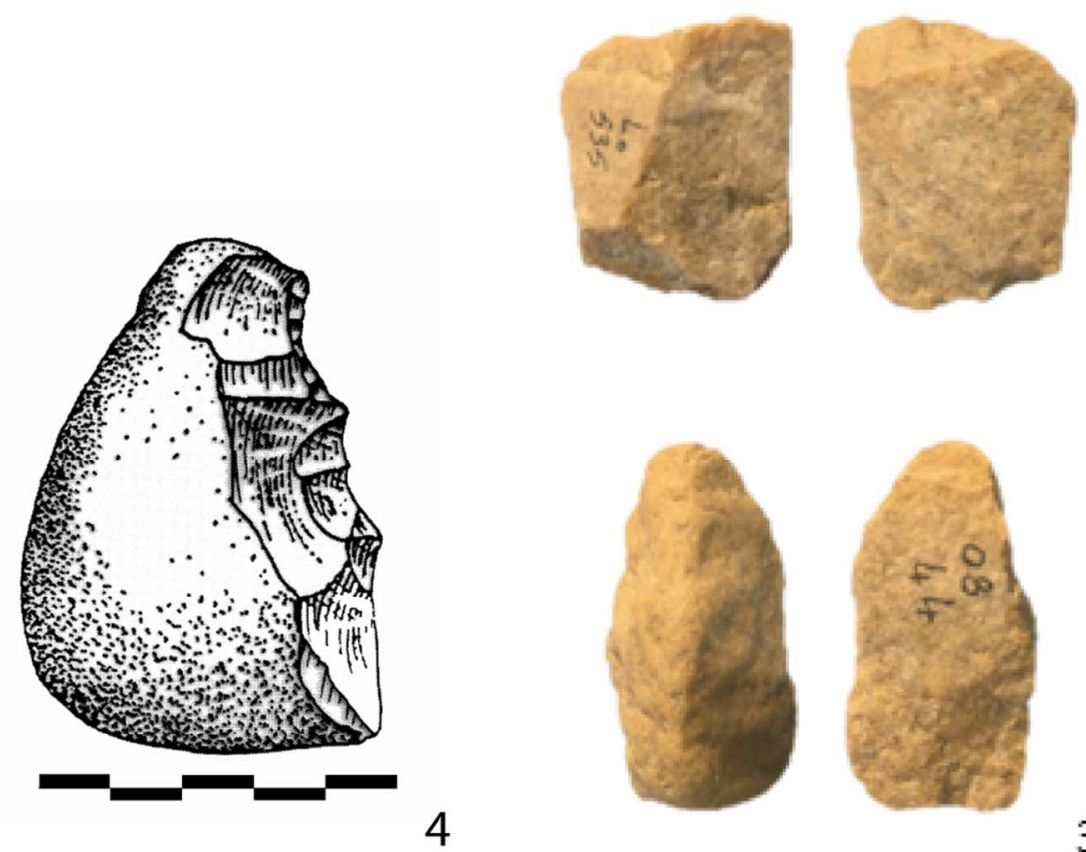

2
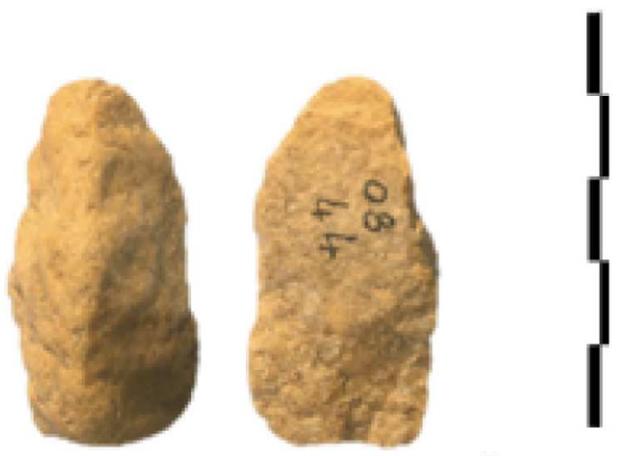

3

Figure 17. Examples of cortical quartz flakes with some removals $(1,2,3)$. Denticulate on a cortical flake (4) (drawing J. Despriée)

$107 \times 112 \mathrm{~mm}(300 \times 300$ DPI $)$ 


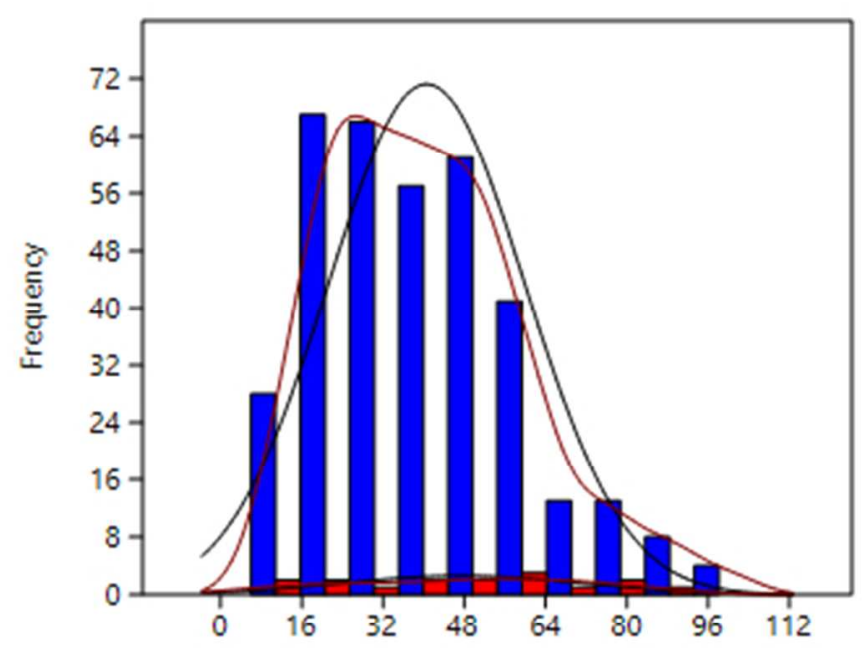

Figure 18. Maximum dimensions (in $\mathrm{mm}$ ) of the retouched (red columns) and non-retouched (blue columns) whole flakes. No evident selection based on dimensions is observed for the retouched pieces.

$103 \times 95 \mathrm{~mm}(96 \times 96 \mathrm{DPI})$ 


\section{OVOID COBBLES}

\section{OVAL PEBBLES}

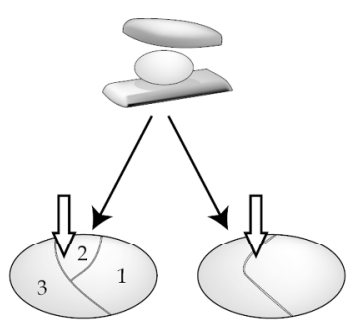

A

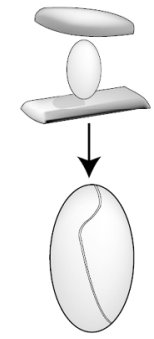

B
POLYEDRIC COBBLES

\section{RECTANGULAR PEBBLES}
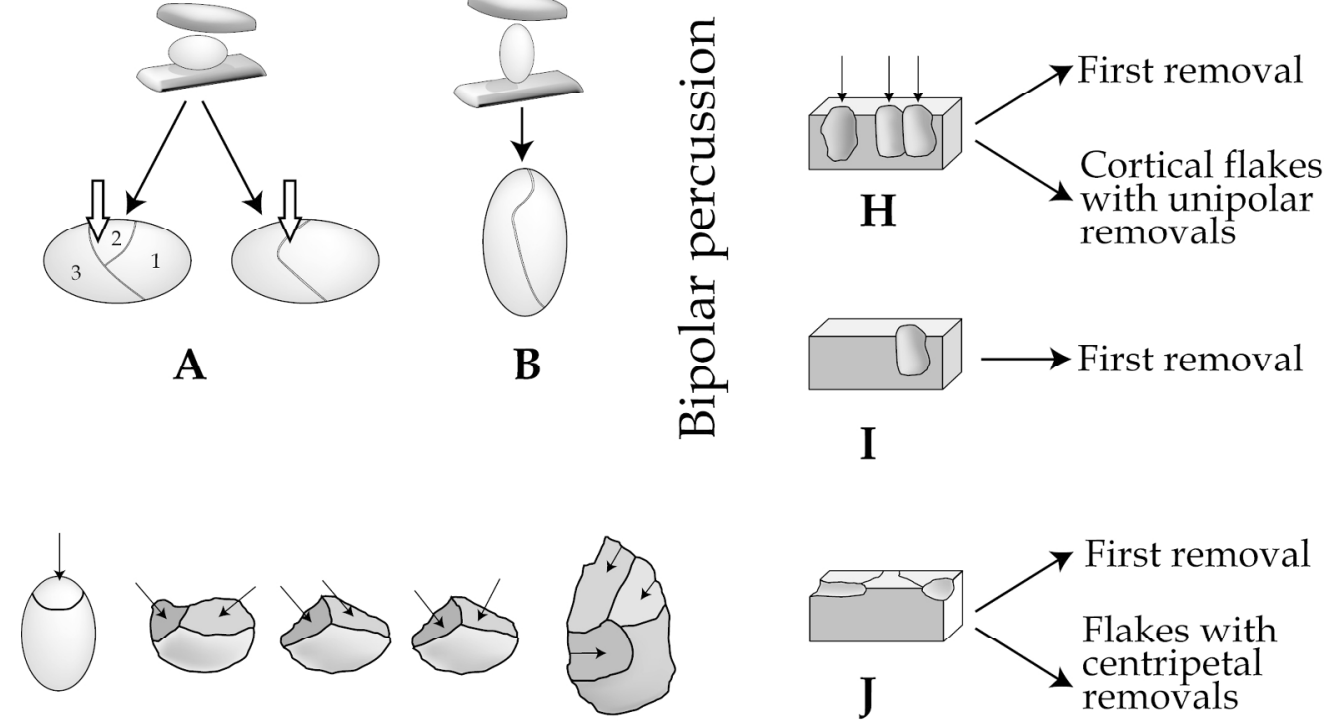

C

D
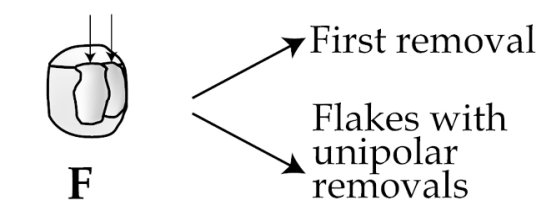

F

$\mathrm{E}$
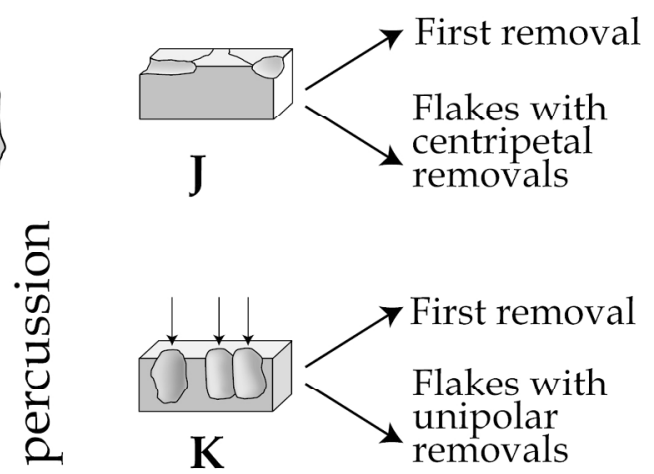
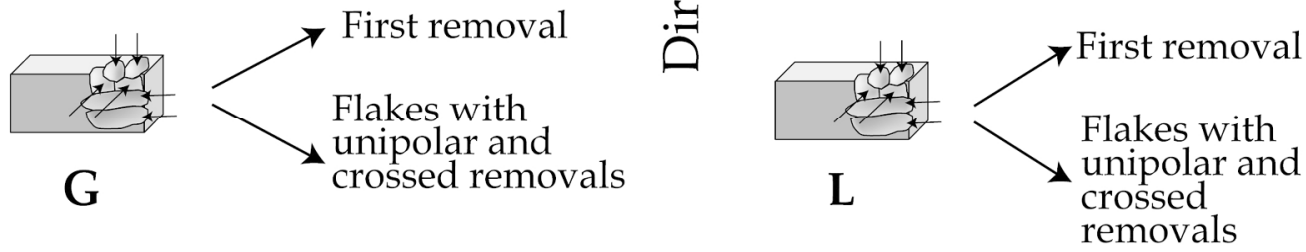

Figure 19. Reduction processes on quartz pebbles at Pont-de-Lavaud according to pebble geometry and the type of percussion A. Bipolar technique with pebbles broken on the longest face; B. Bipolar technique with pebbles broken on the tip; C. Pebbles with one removal; D. Pointed or linear pebble-tools with two removals ; E. Pointed pebble-tools including the proto-biface; F. Cores on oval pebbles with unipolar removals on one flaking surface with cortical platform; G. and L. Cores on pebbles with unipolar removals and two orthogonal

flaking surfaces; $\mathrm{H}$. and $\mathrm{K}$. Cores on rectangular pebbles with unipolar removals on one flaking surface located on the side of the pebble with a cortical platform; I. Rectangular pebbles with one removal on the edge; J. Cores on rectangular pebbles with unipolar removals on one flaking surface located on the largest face of the pebble with a cortical platform. 
Table 1: Composition of our corpus with artefacts attesting clear hominin activity (in number and ratio) in relation to quartz morphology

\begin{tabular}{|c|c|c|c|c|c|c|}
\hline $\begin{array}{l}10 \\
11\end{array}$ & \multicolumn{2}{|c|}{ Ovoid pebbles/cobbles } & \multicolumn{2}{|c|}{ Polyhedral pebbles/cobbles } & \multicolumn{2}{|c|}{$\begin{array}{l}\text { Indeterminate } \\
\text { pebbles/cobbles }\end{array}$} \\
\hline \multicolumn{7}{|l|}{12 Direct percussion } \\
\hline 131 isolated removal & 21 & $1.6 \%$ & 48 & $3.6 \%$ & 0 & - \\
\hline 14 Unipolar unifacial cores & 46 & $3.5 \%$ & 31 & $2.3 \%$ & 0 & - \\
\hline $\begin{array}{l}15 \text { Cores with } 2 \text { orthogonal } \\
16 \\
\text { flaking surfaces }\end{array}$ & 34 & $2.6 \%$ & 35 & $2.6 \%$ & 3 & $0,2 \%$ \\
\hline 17 Centripetal cores & 17 & $1.3 \%$ & 7 & $0.5 \%$ & & \\
\hline 19 Broken pebbles & 13 & $1 \%$ & 20 & $1.5 \%$ & 5 & $0,4 \%$ \\
\hline $\begin{array}{l}20 \text { Flakes } \\
21\end{array}$ & 132 & $\begin{array}{l}10 \% \text { including } 60 \% \\
\text { first cortical flakes }\end{array}$ & 110 & $\begin{array}{l}8.3 \% \text { including } 70 \% \\
\text { first cortical flakes }\end{array}$ & 37 & $2,8 \%$ \\
\hline $\begin{array}{l}22 \text { Retouched pointed } \\
23 \text { products }\end{array}$ & 48 & $3.6 \%$ & 0 & - & 0 & - \\
\hline 24 Other flake-debris-tools & 3 & $0.2 \%$ & 0 & - & 0 & - \\
\hline 25 Choppers & 27 & $2 \%$ & 10 & $0.7 \%$ & 0 & - \\
\hline \multicolumn{7}{|l|}{26 Bipolar percussion } \\
\hline 27 Unipolar & 17 & $1.3 \%$ & 19 & $1.4 \%$ & & \\
\hline 282 orthogonal surfaces & 11 & $0.8 \%$ & 13 & $1 \%$ & 4 & $0,3 \%$ \\
\hline 291 removal & 1 & $0.1 \%$ & 3 & $0.2 \%$ & & \\
\hline${ }^{30}$ Broken pebbles & 126 & $12.1 \%$ & 63 & $4.8 \%$ & 1 & $0.1 \%$ \\
\hline 31 Split pebbles & 25 & $1.9 \%$ & 0 & - & & \\
\hline 32 Flakes & 36 & $2.7 \%$ & 6 & $0.4 \%$ & 2 & $0.1 \%$ \\
\hline \multicolumn{7}{|l|}{$\begin{array}{l}33 \\
34\end{array}$} \\
\hline $\begin{array}{l}34 \text { Cores with } 2 \text { orthogonal } \\
35 \text { flaking surfaces }\end{array}$ & - & - & 1 & $0.1 \%$ & 1 & $0.1 \%$ \\
\hline 37 Flakes & - & - & 5 & $0.4 \%$ & 41 & $3.1 \%$ \\
\hline 38 Broken pebbles & - & - & 63 & $4.8 \%$ & 28 & $2.1 \%$ \\
\hline 39 Debris & - & - & 105 & $7.9 \%$ & 103 & $7.8 \%$ \\
\hline 40 TOTAL & 557 & - & 539 & - & 225 & - \\
\hline
\end{tabular}




\begin{tabular}{|c|c|c|c|}
\hline Sites & Other raw materials & Quartz & References \\
\hline $\begin{array}{l}\text { Dmanisi } \\
\text { (Georgia) }\end{array}$ & $\begin{array}{l}\text { Local } \\
\text { Basalt/Andesite } 35.9 \% / 18 \% \\
\text { Tuff/Silicied Tuff } \\
27.1 \% / 4.2 \% \\
\text { Sandstone } 3.3 \% \\
\text { Quartzite } 1.7 \% \\
\end{array}$ & $2.1 \%$ & $\begin{array}{l}\text { Mgeladze et al., } \\
2011\end{array}$ \\
\hline $\begin{array}{l}\text { Bogatyri } \\
\text { (Russia) }\end{array}$ & $\begin{array}{l}\text { Local } \\
\text { Gray dolomite } \\
\text { Siltstone }\end{array}$ & - & $\begin{array}{l}\text { Shchenlinsky et } \\
\text { al., 2008, } 2010\end{array}$ \\
\hline Rodniki (Russia) & $\begin{array}{l}\text { Local Gray dolomite } \\
\text { Siltstone }\end{array}$ & - & $\begin{array}{l}\text { Shchenlinsky et } \\
\text { al., 2008, } 2010\end{array}$ \\
\hline Pirro-Nord (Italy) & $\begin{array}{l}\text { Local } \\
\text { Cretaceous flint } 100 \%\end{array}$ & - & $\begin{array}{l}\text { Arzarello et al., } \\
2006,2013, \\
2015\end{array}$ \\
\hline Monte-Poggiolo (Italy) & $\begin{array}{l}\text { Local } \\
\text { Flint } \\
\text { Rare limestone and chert }\end{array}$ & - & $\begin{array}{l}\text { Peretto et al., } \\
\text { 1998; }\end{array}$ \\
\hline $\begin{array}{l}\text { Fuente Nueva } 3 \\
\text { Barranco Leon } \\
\text { (Orce, Spain) } \\
\end{array}$ & $\begin{array}{l}\text { Local and semi-local Flint } \\
\text { Local silicified limestone and limestone }\end{array}$ & - & $\begin{array}{l}\text { Toro-Moyano et } \\
\text { al., } 2009 \\
\text { Barsky et al., } 2010\end{array}$ \\
\hline $\begin{array}{l}\text { Sima del Elefante } \\
\text { TE7-TE14 (Spain) } \\
\text { Gran Dolina TD3-4 } \\
\text { (Spain) }\end{array}$ & $\begin{array}{l}\text { Neogene and Cretaceous chert }(<2 \mathrm{~km}) 72.1 \% \\
\text { Limestone } 27.1 \%\end{array}$ & $3.5 \%$ & $\begin{array}{l}\text { Lombera-Hermida } \\
\text { de et al., } 2015 \\
\text { Carbonell et al., } \\
1999 \\
\end{array}$ \\
\hline $\begin{array}{l}\text { Gran Dolina TD6 } \\
\text { (Spain) }\end{array}$ & $\begin{array}{l}\text { Local and semi-local } \\
\text { Neogene chert } 39.1 \% \\
\text { Cretaceous chert } 9.8 \% \\
\text { Quartzite } 13.1 \% \\
\text { Sandstone } 9 \% \\
\text { Limestone } 9.5 \% \\
\end{array}$ & $7.7 \%$ & $\begin{array}{l}\text { Lombera-Hermida } \\
\text { de et al., } 2015\end{array}$ \\
\hline La Boella (Spain) & $\begin{array}{l}\text { Local } \\
\text { Chert 76.2\% } \\
\text { Quartzite } \\
\text { Schist } \\
\text { Sandstone } \\
\text { Granite } \\
\end{array}$ & $3.7 \%$ & $\begin{array}{l}\text { Vallverdu et al., } \\
2014\end{array}$ \\
\hline Vallparadis (Spain) & $\begin{array}{l}\text { Local } \\
\text { Lydite } \\
\text { Flint } \\
\text { Quartzite } \\
\text { Metamorphic rock } \\
\end{array}$ & $70 \%$ & $\begin{array}{l}\text { Martinez et al., } \\
2009,2014\end{array}$ \\
\hline Le Vallonnet (France) & Limestone $100 \%$ & - & $\begin{array}{l}\text { Lumley de et al., } \\
1988\end{array}$ \\
\hline Pradayrol (France) & $\begin{array}{l}\text { Quartzite } \\
\text { Limestone }\end{array}$ & - & $\begin{array}{l}\text { Guadelli et al., } \\
2012\end{array}$ \\
\hline Soleihac (France) & $\begin{array}{l}\text { Local } \\
\text { Basalt } \\
\text { Flint } \\
\text { Granite }\end{array}$ & $57.6 \%$ & Bracco, 1991 \\
\hline Happisburgh 3 (UK) & Local flint & - & Parfitt et al., 2010 \\
\hline Pakefield (UK) & Local flint & - & Parfitt et al., 2005 \\
\hline Kärlich A (Germany) & Quartzite & presence & Bosinski, 2006 \\
\hline
\end{tabular}

Table 2. Proportion of quartz and raw materials in a selection of Early sites. 

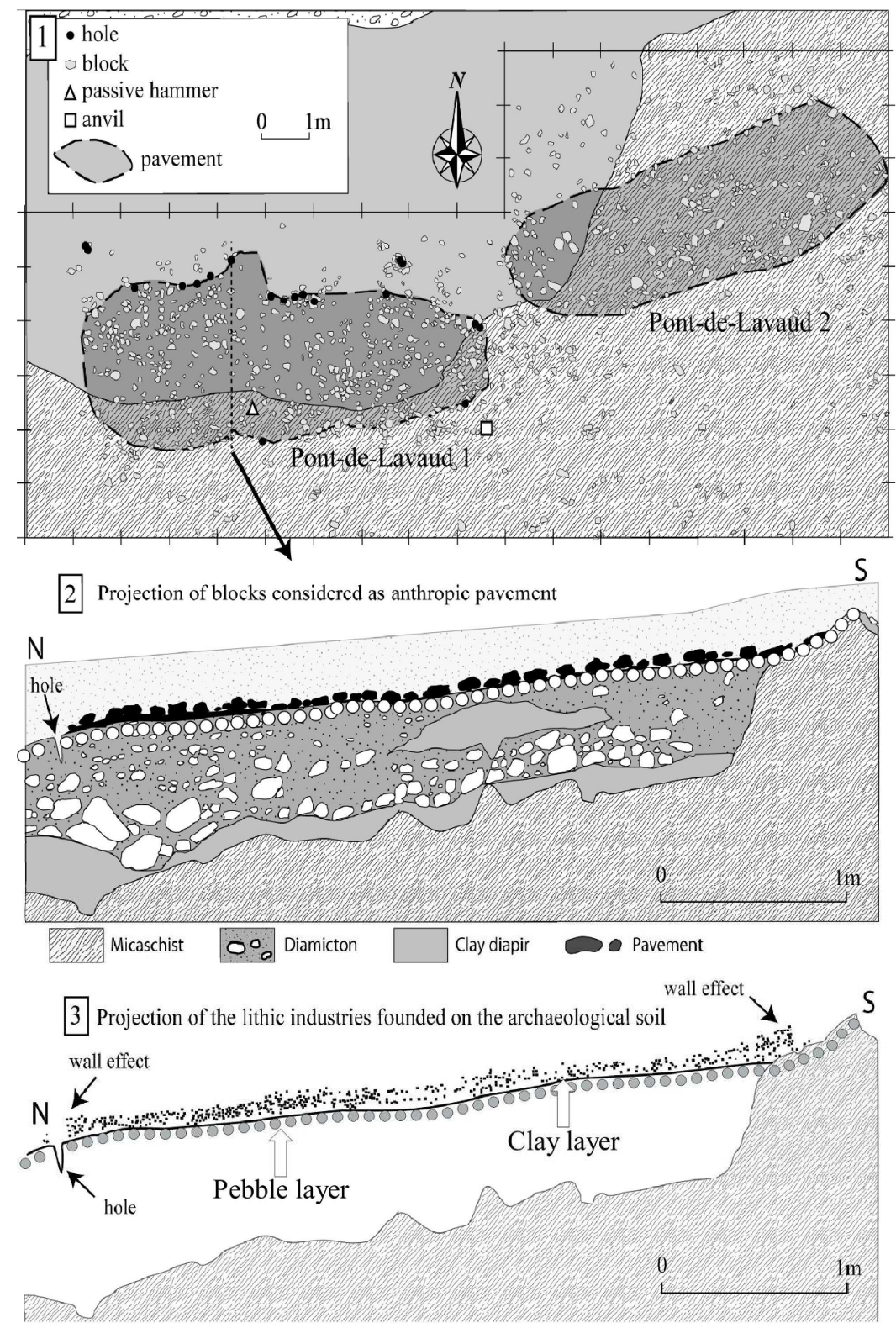

Suppl. 1. View of the accumulation surfaces (Pavement) Pont-de-Lavaud 1 and Pont-de-Lavaud 2, corresponding to concentrations of blocks with linear borders and peripheral holes. 1: Spatial distribution of the vein quartz manuports (blocks $\geq 10 \mathrm{~cm}$ long). 2 and 3: Vertical sections show the links between paving stones (2) and accumulation of lithic artefacts (3) with wall-effect (after Despriée et al, 2010, 1011).

$$
167 \times 250 \mathrm{~mm}(299 \times 299 \mathrm{DPI})
$$




\section{Cobble layer}

Cobble layer

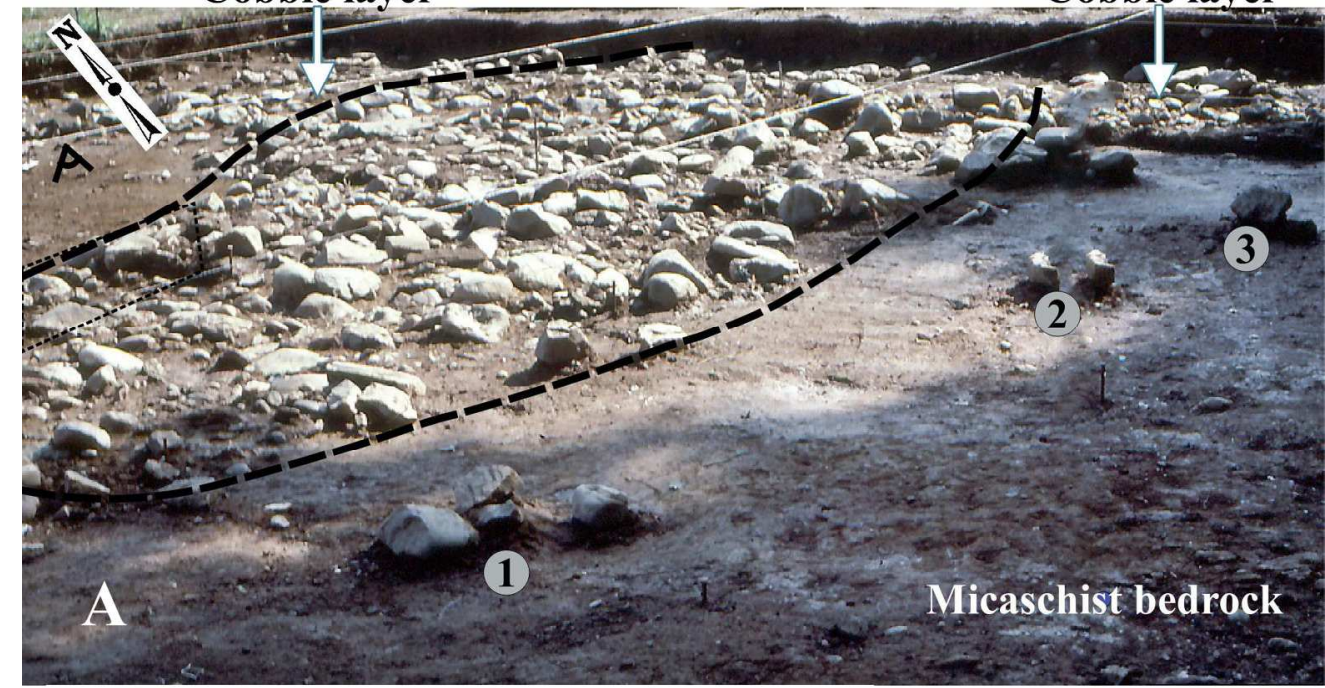

- Edge of Pont-de-Lavaud 1 pavement $<----$ View supp 2b

(1) Wedding

Supp. 2A: Stone accumulation of Pont-de-Lavaud 1. The view from the south also shows the large isolated peripheral blocks on the micaschist bedrock. Suppl. 2 B: Holes surrounded with quartz cobbles on the northern edge (photos J. Despriée).

$170 \times 112 \mathrm{~mm}(299 \times 299 \mathrm{DPI})$ 


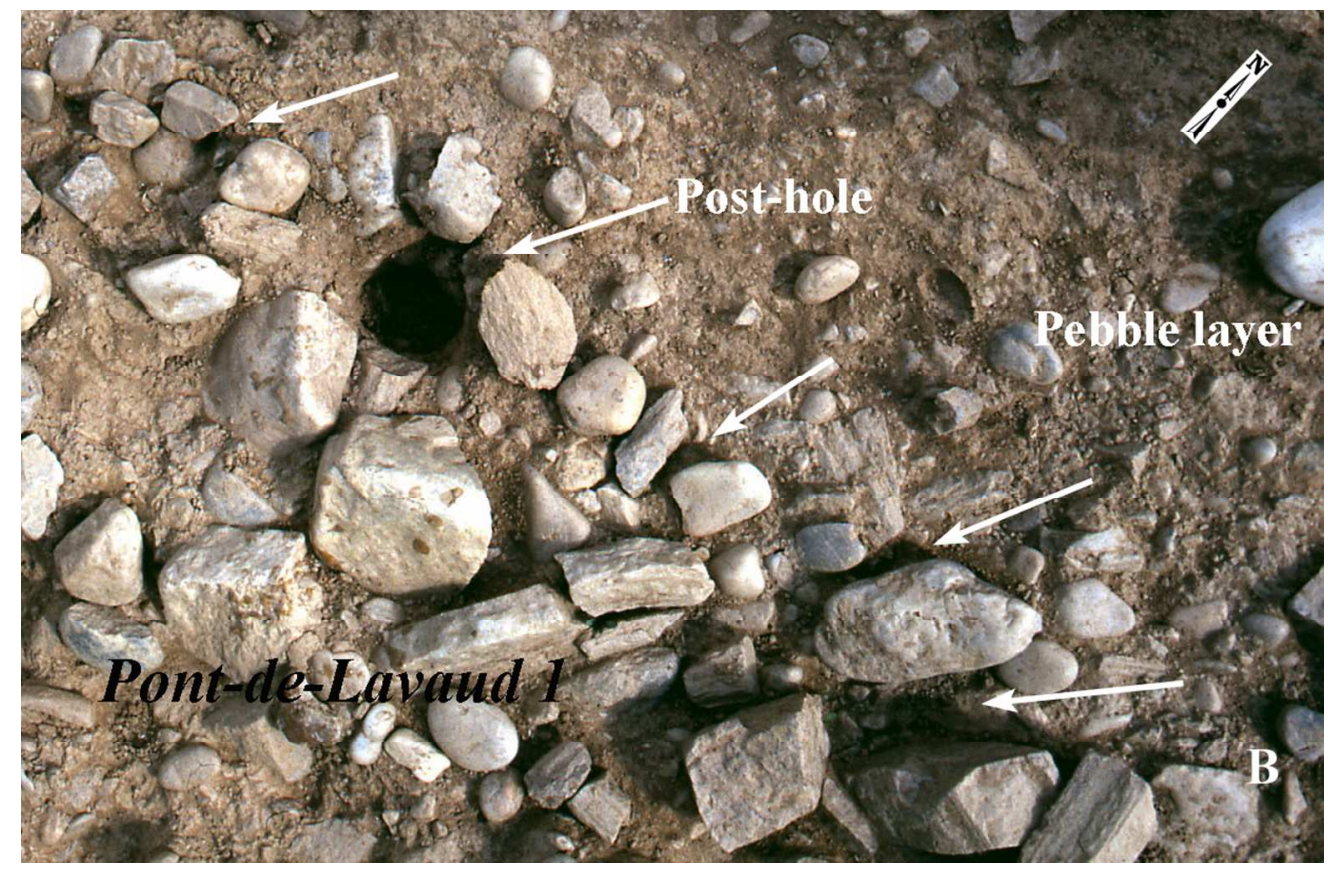

Supp. 2A: Stone accumulation of Pont-de-Lavaud 1. The view from the south also shows the large isolated peripheral blocks on the micaschist bedrock. Suppl. 2 B: Holes surrounded with quartz cobbles on the northern edge (photos J. Despriée).

$435 \times 285 \mathrm{~mm}(72 \times 72 \mathrm{DPI})$ 


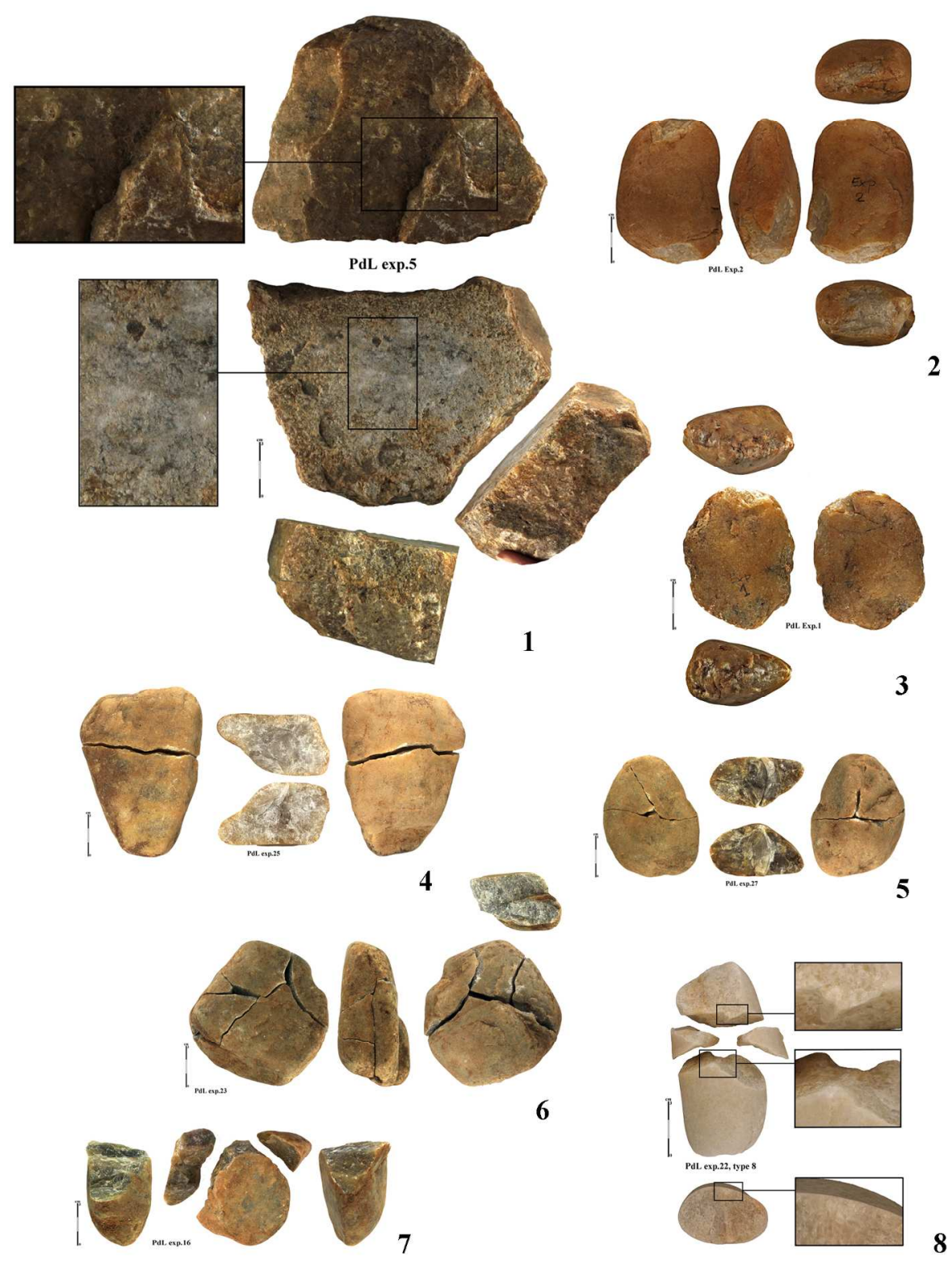

Supp. 3. Photographs of experimental artefacts. (1) Block of vein quartz used as an anvil with impacts on the obverse end and lateral crushing; $(2,3)$. Amygdaloid cobbles used as hammer stones, with use scars; $(4,5)$ Cobbles broken by one blow (types 5 and fragments $7 \mathrm{a}, 7 \mathrm{c}$ ): impact marks, cone and crushing on reverse face; $(6,7)$ Cobbles broken by two blows (types 6 and fragments $7 c, 7 d)$; impact marks, cones and crushing on the opposite surface; (8). Cobble broken by three blows (type 6 with debris type 8 )

(Experimentation by J. Despriée and P. Alilaire, photos G. Courcimault).

\section{$170 \times 219 \mathrm{~mm}(300 \times 300 \mathrm{DPI})$}


Suppl. 4. Partial bifacial piece on quartz. Both sides of the pebble were shaped by alternate striking (photos $\mathrm{M}-\mathrm{H}$. Moncel).

$187 \times 68 \mathrm{~mm}(300 \times 300$ DPI) 